\title{
The Missing Link Between Financial Constraints and Productivity
}

Marialuz Moreno-Badia and Veerle Slootmaekers 



\title{
IMF Working Paper
}

\author{
European Department
}

The Missing Link Between Financial Constraints and Productivity

\author{
Prepared by Marialuz Moreno-Badia and Veerle Slootmaekers ${ }^{1}$ \\ Authorized for distribution by Bob Traa
}

April 2009

\begin{abstract}
This Working Paper should not be reported as representing the views of the IMF.

The views expressed in this Working Paper are those of the author(s) and do not necessarily represent those of the IMF or IMF policy. Working Papers describe research in progress by the author(s) and are published to elicit comments and to further debate.
\end{abstract}

The global financial crisis has reopened the debate on the potential spillover effects from the financial sector to the real economy. This paper adds to that debate by providing new evidence on the link between finance and firm-level productivity, focusing on the case of Estonia. We contribute to the literature in two important respects: (i) we look explicitly at the role of financial constraints; and (ii) we develop a methodology that corrects for the misspecification problems of previous studies. Our results indicate that young and highly indebted firms tend to be more financially constrained. Overall, a large number of firms shows some degree of financial constraints, with firms in the primary sector being the most constrained. More importantly, we find that financial constraints do not lower productivity for most sectors.

JEL Classification Numbers: D24, G32, O16, P27

Keywords: financing constraints, productivity, SMEs

\section{Author's E-Mail Address:MMorenobadia@imf.org and Veerle.Slootmaekers@,oecd.org}

\footnotetext{
${ }^{1}$ Moreno Badia (MMorenobadia@,imf.org): International Monetary Fund; Slootmaekers (Veerle.Slootmaekers@,oecd.org): Organisation for Economic Co-operation and Development and Catholic University of Leuven, LICOS Centre for Institutions and Economic Performance. We would like to thank Larissa Merkulova and Kadri Rohulaid of the Centre of Registers and Infosystems for the data and valuable clarifications on the Registrar's Office database. We also thank Franek Rozwadowski, and seminar participants at the International Monetary Fund, the European Commission, LICOS and the CAED conference in Budapest for helpful comments and suggestions. Most of all, we would especially like to thank Nobuo Yoshida for his thoughtful insights and ideas. The views expressed herein are those of the authors and should not be held to represent those of the institutions of affiliation.
} 


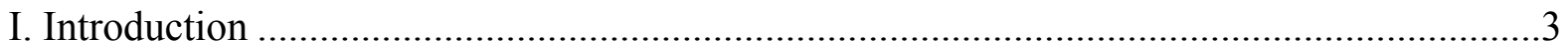

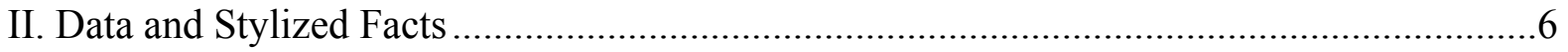

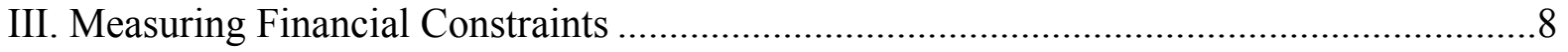

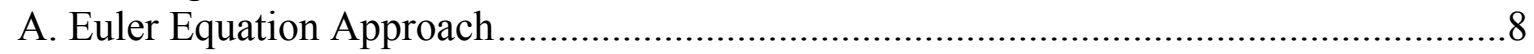

B. Empirical Model............................................................................................... 9

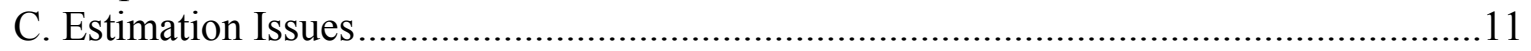

D. Results on Financial Constraints ...................................................................... 12

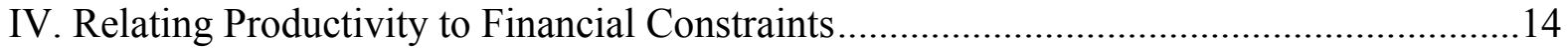

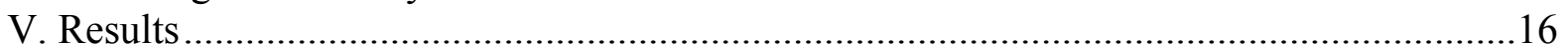

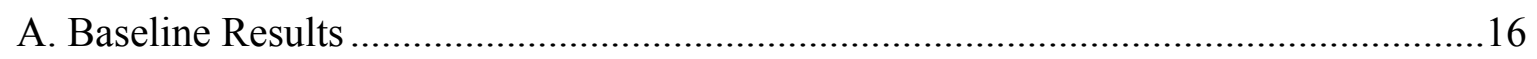

B. Robustness Checks ........................................................................................ 17

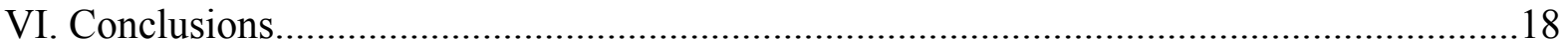

Tables

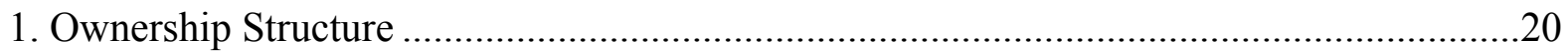

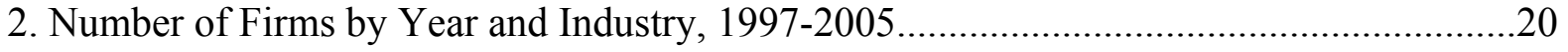

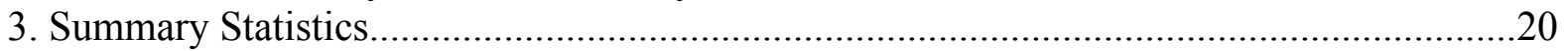

4. Euler Equation Specification, Estimated Using System GMM ......................................21

5. Magnitude and Distribution of Financing Constraints by Sector ...................................22

6. Correlation between Financial Constraints and Other Firm Characteristics .....................22

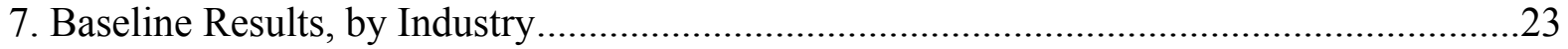

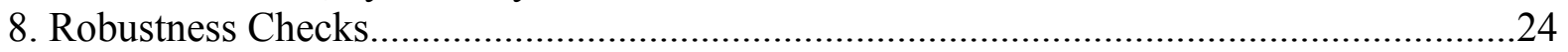

Figures

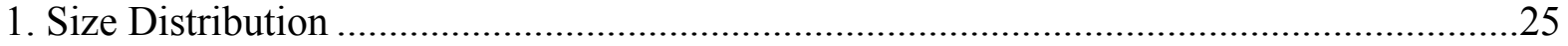

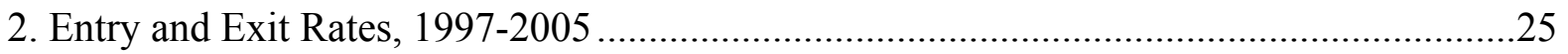

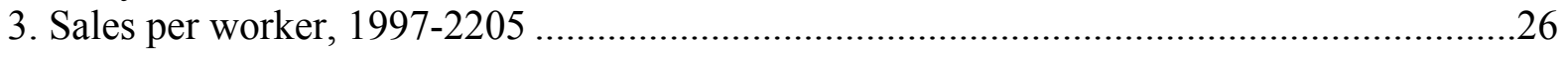

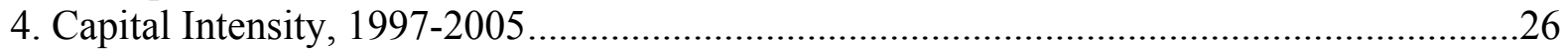

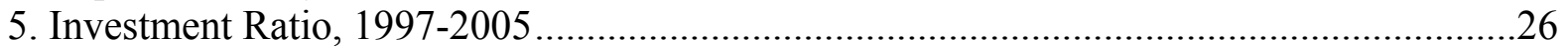

6. Mean Financial Constraints by Industry, 1998-2005 .................................................27

Appendices

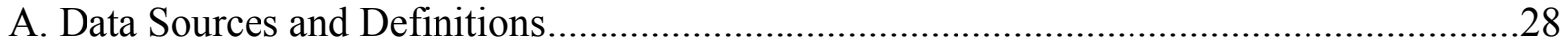

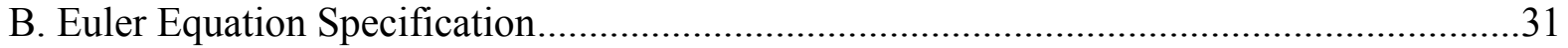

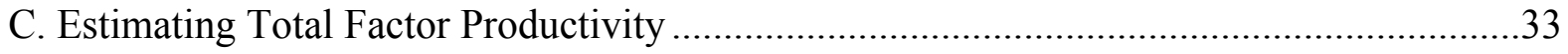

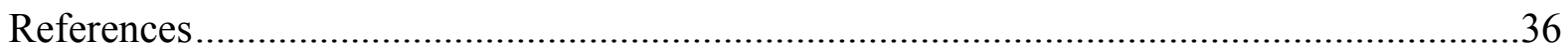




\section{INTRODUCTION}

The financial turmoil that began in the United States has resulted in a severe credit crunch in numerous countries, including emerging economies. This has reopened the debate on the potential spillover effects from the financial sector to the real economy. A growing empirical evidence suggests there is a positive relationship between financial development and economic growth. ${ }^{2}$ Although the precise channels through which finance affects growth are not yet well understood, the existing literature underscores that, by mitigating information and transactions costs, a well-developed financial system can influence saving rates, investment decisions, and productivity—which embodies technological innovation.

This paper focuses on the link between access to finance and productivity, given the central role of the latter for economic growth and development. ${ }^{3}$ In particular, we examine whether financial constraints have reduced firm-level productivity in Estonia. To be sure, Estonia has experienced two rapid credit growth cycles financed by foreign capital: one in the mid-1990s, interrupted by the Asian and Russian crises, and another from 2001, following the entry of Scandinavian strategic investors into the Estonian banking system, which is now coming to an end (Lättemäe, 2007). However, credit has not been evenly distributed across sectors as the main beneficiaries of the rapid credit expansion have been the financial and real estate sectors. The case of Estonia is also interesting because, despite significant financial deepening and rapid credit growth, more than 60 percent of corporate investment in Estonia is financed with internal funds. ${ }^{4}$ Moreover, the 2006 progress report on the implementation of the Lisbon Strategy argues that Estonia's adoption of new technologies is hindered by insufficient access to capital. ${ }^{5}$ This evidence suggests that some firms may have been constrained in their investment and input decisions, with a potentially detrimental impact on productivity relative to unconstrained firms. Understanding whether this was the case is particularly important in the current environment in which credit growth in Estonia has slowed down considerably and firms may face increasing financing constraints that could dampen growth.

\footnotetext{
${ }^{2}$ See the surveys by Levine $(1997,2005)$ for a review of the theoretical and empirical literature.

${ }^{3}$ Access to finance can clearly affect capital accumulation. However, the literature has identified innovation and technological progress as the main drivers of growth over extended periods of time (see, for example, Solow, 1957). In fact, Moreno Badia (2007) finds that most of Estonia's income convergence with the EU-15 since the mid-1990s stems from closing the gap in total factor productivity.

${ }^{4}$ This could be due to financial frictions but may also be explained by the fact that, since 2000, retained earnings are not taxed in Estonia.

${ }^{5}$ According to the same report, access to loans is hindered by many factors, including, insufficient guarantees or own capital, a short financial history or insufficient business plan, and financial institutions' disproportionally large costs of processing small-scale loans.
} 
On the theoretical side, several models have articulated the mechanisms by which the financial system may increase productivity. The main idea is that access to finance facilitates firms' investment in long-duration and productivity-enhancing projects. These projects are more easily undertaken when there are liquid financial markets, given that investors can sell their stake in the project if they need their savings before the project matures (see, for example, Levine, 1991; and Bencivenga et al., 1995). Also, financial markets can help by evaluating prospective entrepreneurs, mobilizing savings to finance the most promising investment projects, and diversifying the risks associated with these innovative activities (King and Levine, 1993a). In addition, perfect credit markets increase the propensity to engage in long-term, productivity-enhancing investment by decreasing the level of liquidity risk involved in those investments (see Aghion et al., 2005). It follows from these models that financial frictions will result in lower productivity by hampering investment in the highest quality projects or newest vintages of capital.

The empirical literature on the relationship between finance and productivity is scant, with most studies focusing on the role of financial development. For example, at the macro level, King and Levine (1993a, 1993b) find that financial development has a positive effect on productivity. Beck et al. (2000) show that financial intermediaries help economic growth through more efficient resource allocation rather than through investment or saving. Arestis et al. (2003) argue that financial policies affect growth mainly through total factor productivity (TFP). Rioja and Valev (2004) find that finance has a strong positive effect on productivity growth primarily in more developed economies. At the micro level, Ayyagari et al. (2007) use a large panel of firms in 47 developing countries to show that external finance increases innovation. Using survey data, Canepa and Stoneman (2008) find that financial factors are constraints to innovation in the U.K. Although these papers study various aspects of financial development or access to finance, they put little or no emphasis on the direct effect of financial constraints on productivity. They also tend to rely on country-specific data or firm-level data that do not allow TFP to be estimated accurately. Our paper is closer in spirit to Gatti and Love (2008) who find that access to credit had a positive impact on TFP in Bulgaria. Their empirical strategy is to estimate two separate equations: (i) a production function equation to obtain firm-level productivity estimates; and (ii) a productivity equation, whose main regressor is a measure of access to finance. This approach suffers, however, from two shortcomings. First, the productivity equation does not control for lagged productivity and could suffer from serial correlation if productivity follows a first-order Markov process as in Levinsohn and Petrin (2003). Second, productivity estimates may be biased as they do not take into account the effect that access to finance may have on a firm's input decisions.

Our paper contributes to this literature in two important ways. First, we look explicitly at the impact of financial constraints on productivity. Second, we develop a methodology that 
corrects for the misspecification problems of Gatti and Love (2008). ${ }^{6}$ To identify the effect of financial constraints on Estonian firms' productivity, we use a unique firm-level data set covering the primary, secondary, and services sectors for the years 1997 to 2005 and proceed in two steps. First, we construct a measure of financial constraints by building on the literature of investment sensitivity to internal finance. Since firms may transit from different financial states, we allow this measure to vary with a set of firm characteristics that, a priori, are considered to determine the ability of a firm to attract external finance. The advantage of this approach is that it allows us to capture differences in the degree of financial constraint across firms and time. Second, we develop a structural approach similar to the one used in the trade literature where we estimate a production function equation that directly includes our measure of financial constraints as a regressor while allowing productivity to evolve as a first-order autoregressive process. ${ }^{7}$ To limit the potential simultaneity bias between productivity shocks and financial frictions, we consider the lag of the financial constraints measure and control for unobserved industry-fixed characteristics. ${ }^{8}$

Our main findings are as follows. First, we show that the investment of both young and highly indebted firms is more sensitive to internal funds, and, as expected, foreign firms tend to be less financially constrained than the average Estonian firm. Overall, a large number of firms display some degree of financial constraint, with firms in the primary sector the most constrained. Second, we find that financial constraints do not have an impact on productivity for most sectors, with the exception of R\&D and business services, where the dampening effect of financial constraints on productivity is remarkably large. These findings are robust to several sensitivity tests and underscore the importance of credit allocation.

The remainder of this paper is organized as follows. Section II describes the data. Section III discusses the previous literature testing for the presence of firm-financing constraints and estimates the baseline measure of financial constraints. Section IV outlines the estimation strategy to analyze the impact of financial constraints on productivity. Section $\mathrm{V}$ presents the results. Section VI concludes.

\footnotetext{
${ }^{6}$ A previous version of this paper compares the results of this new approach with those of a two-equation approach, highlighting significant differences (see, Moreno Badia and Slootmaekers, 2008).

${ }^{7}$ See, for example, Van Biesebroeck (2005), Amiti and Konings (2007), De Loecker (2007), and Fernandes (2007).

${ }^{8}$ The simultaneity bias arises because investors may ration credit to the less productive firms.
} 


\section{DATA AND StYlized FACTS}

We use firm-level data provided by the Estonian Business Registry covering the period 1997 to 2005. The data set is an unbalanced panel containing detailed information on balance sheets and income statements of all registered firms in Estonia. Entry and exit are observed, and the number of business entities in the registry more than doubles over the sample period, rising from 21,183 firms in 1997 to 51,385 firms in 2005. However, due to missing information and the exclusion of extreme or unrealistic observations, the data of only 45 percent of the firms in the registry (accounting for about 60 percent of aggregated value added in 2004) can be used. ${ }^{9}$

One of the unique features of the data set is the absence of any size thresholds. About 99 percent of the firms in the data set are small and medium-sized enterprises (SMEs) with less than 250 employees, of which microenterprises (10 or fewer employees) are the dominant form of business organization, accounting for 69 percent of the total number of firms (Figure 1). In addition, more than 90 percent of the firms included in the data set are privately owned (Table 1). The sectors with the largest share of foreign-owned firms are "mining and quarrying" and "manufacturing," but the percentages remain very low. This makes this data set particularly well-suited to analyze the implications of financial frictions since privately owned firms, and SMEs in particular, usually receive a very low share of credit in many emerging markets, despite accounting for a large share of enterprises, employment, and output. The OECD notes that SMEs are, in fact, at a severe disadvantage relative to their larger and more established counterparts, mainly due to monitoring difficulties and asymmetric information (OECD, 2006). As a result, the majority of these firms is often denied any access to the formal credit markets in emerging and developing countries.

Another salient feature of the data set is the availability of data from all economic sectors in Estonia. Table 2 reports the number of firms in the sample by year and broad industry group. Most enterprises (61 percent of the total number of firms) are operating in business services sectors (such as wholesale and retail trade, hotel and restaurants, or transport activities). The manufacturing sector is the second most important sector in Estonia, accounting for 17 percent of the total number of enterprises. The number of firms in the data set increases over time, partly due to an improvement in the coverage. However, most of the new firms are newly registered firms and are thus effectively entrants. Although declining, Estonian entry and exit rates are fairly high by international standards (Figure 2). Exit rates among Estonian firms were particularly high in the late 1990s. The high firm turnover rate may be partly related to the restructuring during the transition period, with the shift from large-scale, state-owned production to smaller private units. Although start-ups and very young firms

\footnotetext{
${ }^{9}$ For a detailed description of the data and definitions, see Appendix A. More detailed information on the data set itself can be found in Masso et al. (2004).
} 
may have innovative products and services and high growth prospects, they typically lack sufficient collateral. According to the OECD, this group in particular faces important obstacles to accessing adequate financing.

For the rest of the analysis, we exclude all financial, insurance and real estate firms, plus public services companies since they are not or are less subject to financial constraints, or their investment behavior depends more on political decisions or broader economic policy than on access to (external) finance. In addition, we exclude state-owned firms since they are more likely to face soft budget constraints, and are not necessarily profit-maximizing agents - a necessary assumption in our productivity estimation in Section IV. ${ }^{10}$

As a preliminary analysis of the impact of financial frictions, we provide some summary statistics on the differences between firms that utilize external finance versus firms that do not. In particular, Table 3 shows that more than half of the firms in our sample have no long-term liabilities on their balance sheets during their entire life span. These firms are on average much smaller in terms of number of employees, sales, or value added, and they are slightly younger. In addition, their capital intensity, labor productivity, and investment rates are considerably lower than those firms that borrow from banks or private investors. Figures 3 through 5 graph trends in key microeconomic variables for firms with long-term liabilities (Debt) compared with firms without them (No debt). Specifically, Figure 3 shows that firms with debt are on average more productive; however, the difference is rather small until the year 2000. However, in more recent years, firms with debt experienced an exponential growth in their labor productivity, whereas no-debt firms' productivity increased only slightly. Figure 4 focuses on capital intensity and shows a comparable pattern. Capital intensity more than doubled, rising from EEK124,000 in 2000 to almost EEK310,000 in 2005 for those firms with long-term liabilities, as opposed to an almost flat trend for the group of firms with no debt. Finally, Figure 5 graphs investment as a ratio of total assets, showing that the ratio is about twice as high for firms utilizing external finance than for those without it over the entire sample. Although the trends in the investment ratio are similar for both groups, the investment ratio of indebted firms declined immediately after the Russian crisis, whereas the no-debt firms responded with one-year lag. In addition, the rate of increase in investment was much higher among indebted firms: the investment ratio rose by merely 1 percentage point for firms without external finance, while that ratio was 22 percent higher than the 1999 level for firms with external debt. Overall, these patterns illustrate fundamental differences in the performance and operation of firms that borrow from banks or private investors versus firms without long-term liabilities. In the rest of the paper, we exploit these observed dissimilarities and try to disentangle the correlation between a more formal

\footnotetext{
${ }^{10}$ See Kornai $(1979,1986)$ for a discussion on soft budget constraints. A series of papers have found that financial constraints were absent or limited in some transition countries and have argued this was due to the persistence of soft budget constraints (see, for example, Budina et al., 2000; Lizal and Svejnar (2002); and Konings et al., 2003).
} 
measure of financing constraints and productivity.

\section{Measuring Financial Constraints}

To construct a measure of financial constraints, we rely on the literature of investment sensitivity to internal finance. Modigliani and Miller (1958) show that, under certain assumptions, including perfect capital markets, internal and external funds are perfect substitutes. Therefore, a firm's financial structure and liquidity should be irrelevant to its investment decisions. Since this influential paper, however, an extensive theoretical literature has shown that capital market imperfections can make external finance more expensive than internal finance, due to informational asymmetries, costly monitoring, contract enforcement, and incentives problems. ${ }^{11}$ As a result, firms with weak balance sheets may have limited access to external finance and are obliged to rely on internally generated cash to finance their investment projects. The majority of the empirical literature has interpreted the excess sensitivity of a firm's investment spending to its ability to internally generate cash as indicating the existence of financial constraints.

The first empirical papers in this field used a $Q$ model of investment to study financing constraints. ${ }^{12}$ Several articles emphasize, however, a number of problems with the $Q$ methodology related to measurement errors, unrealistic assumptions, and identification problems. ${ }^{13}$ This paper follows the more recent literature (among others, Bond et al. 2003; Love, 2003; and Forbes, 2007) and focuses on an Euler equation model of financial constraints. Although the $Q$ theory and Euler equation models of investment depart from the same optimization problem, the assumptions required to estimate the Euler equation are less strong. In addition, Kaplan and Zingales' (1997) critique, who question the approach of Fazzari et al. (1988) of using investment-cash flow sensitivities as a proxy for financing constraints, has not yet been theoretically proven in a dynamic multiperiod setting with investment adjustment costs (Bond et al., 2003). Finally, information on a firm's market value, which is used as a proxy for Tobin's $q$, is available only for publicly listed companies. The Euler equation has the advantage of avoiding the use of share prices.

\section{A. Euler Equation Approach}

The Euler equation is a structural model derived from a dynamic optimization problem under the assumption of symmetric, quadratic costs of adjustment. It relates current investment to

\footnotetext{
${ }^{11}$ See Stein (2001) for a review of the theoretical literature.

${ }^{12}$ The $Q$ theory of investment was pioneered by Tobin (1969) and further extended by Hayashi (1982). We refer to Hubbard (1998) for a review of the empirical literature.

${ }^{13}$ See Schiantarelli (1996) and Hubbard (1998) for a detailed description of these issues.
} 
last period's investment and the marginal product of capital, and has the advantage of controlling for all expectational influences on the investment decision. The main disadvantage is that the structure of adjustment costs is rather restrictive. Besides, the Euler equation approach may fail to detect the presence of financial constraints if the tightness of such constraints is approximately constant over time (Schiantarelli, 1996). While this risk is particularly severe in very short panels, our data covers a period long enough to record changes in individual firms' financial strength and overall macroeconomic conditions. The empirical specification of the Euler equation is as follows (see Appendix B for the derivation):

$$
\left(\frac{I_{i t}}{K_{i t-1}}\right)=\theta_{0}+\theta_{1}\left(\frac{I_{i t-1}}{K_{i t-2}}\right)+\theta_{2}\left(\frac{\text { Sales }_{i t}}{K_{i t-1}}\right)+\theta_{3}\left(\frac{\text { Cash }_{i t}}{K_{i t-1}}\right)+\alpha_{i}+\delta_{t}+\varepsilon_{i t},
$$

where $I_{i t}$ is the investment expenditure of firm $i$ at time $t$; Sales $i t$ is the net revenue received from the sales of products, goods, and services; Cash $_{i t}$ represents a firm's internal financial position, measured by its stock of liquid assets at the start of period $t ; \alpha_{i}$ represents a firm-fixed effect; and $\delta_{t}$ denotes a time dummy. All variables in equation (1) are in real terms and are weighted by one-period lagged capital $(K)$. In this model, the cash stock affects the rate of intertemporal substitution between investment today and investment tomorrow. If a firm is financially constrained, the impact of cash stock on the intertemporal allocation decision will be positive. The more financially constrained a firm is, the larger will be the impact of its available cash stock on the cost of capital. In other words, an increase in cash stock will lower the implied cost of capital, making investment today more attractive than investment tomorrow. This implies that a firm is considered to be financially constrained if the cash coefficient, $\theta_{3}$, is estimated to be positive. The idea behind this equation is that, the larger the sensitivity of investment to cash stock (or cash flow), the more constrained the firm is because it has to rely on its internal funds to finance its investment projects. Although cash stock may be a proxy for future profit opportunities, it has been argued that this would only be the case in the presence of financial constraints (see, for example, Love, 2001) since holding liquid assets is costly. Therefore, a firm, anticipating profitable investment opportunities, will accumulate liquid assets only if it expects to be financially constrained.

\section{B. Empirical Model}

Typically, the literature divides a sample of firms based on a characteristic that is a priori expected to affect financial constraints, and then compares the cash sensitivity of investment for both groups. This approach implies that a firm belongs to the financially constrained or unconstrained group for the entire period of time, without the possibility of transiting between different financial states. In addition, partitioning observations into groups on the basis of a single indicator may not always be a sufficient indicator of liquidity constraints. The severity of financial constraints often varies among firms of the same subgroup because of other factors that are not controlled for. One possible way to address both issues is to use an endogenous switching regression method with unknown sample separation. This 
methodology does not require a prior knowledge of whether a firm is financially constrained, since the probability of a firm facing a high premium on external finance is endogenously determined by multiple firm characteristics (see, for example, $\mathrm{Hu}$ and Schiantarelli, 1998; Hovakimian and Titman, 2006; and Almeida and Campello, 2007). Yet, this approach comes at a cost: one has to make very restrictive assumptions about the underlying investment model. Instead, we estimate and construct for each firm a score of cash sensitivity based on a range of firm characteristics that may affect its ability to attract external finance, while controlling for the information contained in the other factors.

To determine this set of variables, we browse through the existing literature. First, one of the most widely used proxies for the degree of liquidity constraint is firm Size. Smaller firms are likely to be financially constrained for a number of reasons: (i) small firms often lack sufficient collateral; (ii) SMEs tend to show a more volatile pattern of growth and earnings, with greater fluctuations than larger companies; and (iii) large firms can raise debt more easily because they are more diversified and less prone to bankruptcy. All these factors raise the cost of external finance for small firms, thereby supporting the hypothesis that small firms have a higher sensitivity of investment to internal funds. Second, similar to size, Age may proxy for the wedge between the costs of external and internal capital. Agency and information problems are more severe for young firms since they have not yet built a track record that helps investors to distinguish good from bad enterprises. Also the provision of collateral is particularly difficult for start-ups and other relatively young businesses. Third, the ratio of debt to total assets, Leverage, signals two opposite effects. On the one hand, higher debt means that the firm had access to external finance in the past, which may be an indication that the firm does not face liquidity constraints. However, it does not necessarily mean that the firm obtained as much finance as it would have liked, or whether the received loan was below the optimal value. On the other hand, leverage may negatively affect investment expenditures because (i) increased leverage reduces the current funds available for investment (see, for example, Lang et al., 1996); and (ii) highly leveraged firms may face bigger hurdles in accessing external sources of capital (Jensen and Meckling, 1976; Myers, 1977). Finally, Harrison and McMillan (2003) argue that foreign firms are not or less credit constrained because they are more profitable and/or have access to more collateral, and they find evidence supporting their hypothesis. To assess the statistical significance of a given factor in proxying financial constraints, each of the above-discussed variables is interacted with $\left(\mathrm{Cash}_{i t} / K_{i t-1}\right)$ in equation (1):

$$
\left(\frac{I_{i t}}{K_{i t-1}}\right)=\theta_{0}+\theta_{1}\left(\frac{I_{i t-1}}{K_{i t-2}}\right)+\theta_{2}\left(\frac{\text { Sales }_{i t}}{K_{i t-1}}\right)+\left(\frac{\text { Cash }_{i t}}{K_{i t-1}} \times \Omega_{i t}\right)+\alpha_{i}+\delta_{t}+\varepsilon_{i t},
$$

with

$$
\Omega_{i t}=\delta_{1} I_{1}+\ldots+\delta_{N} I_{N}+\lambda_{1} \ln (\text { Size })_{i t}+\lambda_{2} \ln (\text { Age })_{i t}+\lambda_{3} \text { Leverage }_{i t}+\lambda_{4} \text { Foreign }_{i t} .
$$

Size $_{i t}$ is measured as total assets at the beginning of period $t$; $A g e_{i t}$ is the age of the firm at the 
beginning of period $t$, based on the entry date in the registry; Leverage $e_{i t}$ stands for the ratio of long-term liabilities to total assets at the beginning of period $t$; Foreign $n_{i t}$ is a dummy equaling one if more than 50 percent of the shares is foreign owned at time $t$. Finally, we take into account differences in the sensitivity of investment to cash across sectors, that is, we allow for a different intercept for each two-digit industry $\left(I_{1}, \ldots, I_{N}\right)$. The estimated coefficients for the $\delta$ 's and the $\lambda$ 's are then used to calculate a firm-specific score of financial constraints $\hat{F}_{i t}^{n}$, based on the firm's characteristics:

$$
\hat{F}_{i t}^{n}=\hat{\delta}_{n} I_{n}+\hat{\lambda}_{1} \text { Size }_{i t}+\hat{\lambda}_{2} \text { Age }_{i t}+\hat{\lambda}_{3} \text { Leverage }_{i t}+\hat{\lambda}_{4} \text { Foreign }_{i t} .
$$

The bigger the $\hat{F}_{i t}$, the higher the degree of financial constraint. Although the coefficients are constant over the entire sample period, the characteristics of each firm change over time, and, hence, also the degree of its financial constraint.

\section{Estimation Issues}

Since equation (2) is a dynamic investment model with a lagged dependent variable $\left(I_{i t-1} / K_{i t-}\right.$ 2) and unobserved time-invariant firm-specific effects $\left(\alpha_{i}\right)$, we estimate the equation using a generalized method of moments (GMM) estimator. By construction, the fixed effects are correlated with the lagged dependent variable, making standard estimators inconsistent. First differencing the equation removes the fixed effects, eliminating a potential source of omitted-variable bias in the estimation. Yet, the presence of the lagged dependent variable continues to bias the coefficient estimates, and many of the variables in the investment equation are likely to be jointly endogenous - that is, simultaneously determined with the dependent variable or subject to two-way causality.

To control for these biases, Arellano and Bond (1991) developed a two-step GMM estimator that instruments the differenced variables that are not strictly exogenous with all their available lags in levels. Under the assumptions that (i) the explanatory variables are predetermined by at least one period, and (ii) the error terms are not serially correlated, the estimated coefficients will be consistent and efficient. A problem with the original Arellano-Bond estimator is that lagged levels are poor instruments for first differences if the variables are close to a random walk. Arellano and Bover (1995) and Blundell and Bond (1998) describe how the use of lagged first differences as instruments for equations in levels, in addition to the usual lagged levels as instruments for equations in first differences, can increase the efficiency of the estimator. This so-called system GMM method is flexible in generating instruments, and one can test the validity of the assumptions. First, the Sargan and Hansen $J$-tests of overidentifying restrictions tests the null hypothesis of no correlation between the instruments and the residuals, and its statistic has an asymptotic chi-square distribution with degrees of freedom equal to the difference in the number of instruments and regressors. Second, we test for different-order serial correlation in the residuals. The presence of autocorrelation in the error terms would indicate that lags of the dependent variable (and 
any other variables used as instruments that are not strictly exogenous) are in fact endogenous and thus bad instruments. Since first-order autocorrelation is expected, one has to test for second-order serial correlation in the differenced equation. If there is evidence of second-order serial correlation, but not of third-order (or higher), then the level variables lagged by two periods (or more) are valid instruments.

A weakness of the first-difference transformation is that it magnifies gaps in unbalanced panels. To maximize our sample size we use the "orthogonal deviations transformation" of Arellano and Bover (1995). Instead of subtracting the previous observation from the contemporaneous one, this subtracts the average of all future available observations of a variable. No matter how many gaps, because this transformation is computable for all observations except the last for each individual, it minimizes data loss.

\section{Results on Financial Constraints}

The results for the estimation of the Euler equation model are reported in Table 4. Equation (2), with $I_{i t} / K_{i t-1}$ as dependent variable, is estimated for each of the 10 industries separately. We apply a system GMM estimator combining equations in first differences with equations in levels. The instruments used are the lagged values of all right-hand side variables dated $t-3$ and $t-4 .{ }^{14}$ This approach allows for contemporaneous correlation between these variables and shocks to the investment equation, as well as correlation with unobserved firm-specific effects. In other words, all right-hand side variables are treated as potentially endogenous variables in the investment equation.

The autocorrelation test and the robust estimates of the coefficient standard errors assume no correlation across individuals in the idiosyncratic disturbances. Time dummies make this assumption more likely to hold, so they are included in all regressions. In the GMM estimation, year dummies are used as instruments for the equations in levels only. Additionally, each regression includes interactions of the variable $\operatorname{Cash}_{i t} / K_{i t-1}$ with two-digit industry dummies $\left(I_{1}, \ldots, I_{N}\right)$ to allow for differences in financial constraints across subsectors in each industry. To keep a clear overview, neither the time dummies nor the two-digit industry intercepts are reported in Table 4; however, we report the Wald test of the null hypothesis that both groups of variables are jointly insignificant.

Since we have more instruments than exogenous variables, we have a number of overidentifying restrictions in each regression. Since the Sargan statistic is not robust to heteroscedasticity or autocorrelation, we also report the robust Hansen $J$-statistic, which is the minimized value of the GMM criterion function. The Sargan and Hansen tests for overidentifying restrictions are unable to reject the validity of the instruments for each of the industries, and the tests of second-order serial correlation find no evidence of second-order

\footnotetext{
${ }^{14}$ We use only two lags rather than the full possible instrument matrix to avoid the problem of overfitting.
} 
autocorrelation in the differenced residuals. ${ }^{15}$

The coefficients on lagged investment and sales have the correct sign for most specifications, but are much smaller in absolute value than suggested by theoretical predictions. The coefficients are usually positive, with significance fluctuating across specifications. Focusing next on the interactions of the cash variable with the different proxies for liquidity constraints, we find that, contrary to expectation, there are no significant differences in financing constraints based on firm size. This is probably due to the lack of variation in firm size in our sample since 99 percent of the firms are SMEs. The coefficient on $\left(\right.$ Cash $_{i t} / K_{i t-1} \mathrm{x}$ $A g e_{i t}$ ), however, illustrates that in half of the industries older firms face significantly fewer hurdles to accessing external funds. Also, highly indebted firms tend to encounter significant liquidity constraints. Finally, foreign firms seem to have easier access to external capital.

Based on these results, we construct a firm-specific score of financing constraints, using the estimated coefficients and the information we have on the firm's size, age, leverage, ownership structure, and the industry to which the firm belongs. In other words, we calculate for each firm a score based on equation (3). If a firm is not financially constrained, the score $\hat{F}_{i t}$ is censored to zero. ${ }^{16}$ The bigger the $\hat{F}_{i t}$, the higher the degree of liquidity constraint a firm faces. Table 5 provides an overview of the magnitude and distribution of the degree of financing constraint across sectors. A large number of firms seems to be subject to some degree of financial constraint. Overall, the degree of financial constraint tends to be highest in the primary sector ("agriculture" and "mining and quarrying," and "energy, gas, and water supply"). This does not imply, however, that firms in other (less constrained) sectors are not financially constrained. As can be seen in the last column of Table 5, variation across firms is larger in the primary sector and "hotels and restaurants."

Figure 6, which graphs the industry means of the financing constraints over the period 1998-2005, shows wide discrepancies across sectors. In particular, financing constraints were relatively high in "agriculture" over the entire sample period but they have increased even more in recent years. The "mining and quarrying" sector displays a similar upward trend, while the financing constraints remained relatively constant across time for the other sectors. In principle, we would expect financial constraints to ease over time, as the degree of financial intermediation increased in Estonia during this period. However, demand for credit may have increased more than the available funds because of the emergence of new financing needs, with strong economic growth and the entry of new firms. Also, financial

\footnotetext{
${ }^{15}$ Only for sector "renting of machinery and computer" (Ind. 9) we cannot reject the presence of second-order autocorrelation at the 5 percent significance level.

${ }^{16}$ The overall conclusions are similar even if we do not censor the score of financial constraints to zero. A minority of firms has a negative score, but the industry means and medians remain positive. Also, the results for the rest of the analysis are similar.
} 
constraints could be an indication of credit misallocation

As a first indication of the impact of financing constraints on a firm's performance, we look at the correlation between a firm's degree of financing constraint and a number of firm characteristics, such as its value added, labor productivity, TFP, and sales per worker. Table 6 displays the Spearman's rank correlation coefficients for all pairs of variables. This table shows that firms in industries with a higher degree of financial constraint perform worse at all levels than firms in industries with easier access to external funds. The correlation is particularly strong in the case of TFP. In the next sections, we explore this relationship more formally.

\section{Relating Productivity to Financial Constraints}

To analyze the relationship between firm-level productivity and financial constraints, we could in principle estimate a simple productivity equation with financial constraints as main regressor as in Gatti and Love (2008):

$$
t f p_{i t}=\beta_{0}+\beta_{f} \hat{F}_{i t-1}+\beta_{x}^{\prime} X_{i t}+\delta_{j}+\delta_{t}+\varepsilon_{i t},
$$

where $t f p_{i t}$ is estimated using the semi-parametric estimation methodology of Levinsohn and Petrin (2003) — described in detail in Appendix C; and $\hat{F}_{i t-1}$ represents the lagged firm-level measure of financial constraints obtained in Section III.

This approach suffers, however, from two problems. First, Levinsohn and Petrin (2003) assume firm productivity follows a first-order Markov process, while equation (4) does not control for lagged productivity and thus suffers from serial correlation. Since $t f p_{i t-1}$ would be part of the error term in that case and financial constraints are endogenous with respect to productivity, our estimates would be inconsistent. Even if we were to control for lagged productivity there will be a second problem. Conditional on lagged productivity, we would still be assuming that current productivity depends on financial constraints and other determinants that are known to the firm in advance. Yet, the Markov process assumption in the Levinsohn-Petrin methodology implies that, conditional on lagged productivity, current firm productivity should be a surprise. Therefore, if we were to estimate productivity without controlling for financing constraints, the identification conditions for the productivity would be violated and the estimates would be biased.

To control for these issues, we incorporate financial constraints directly as a regressor in the production function equation:

$$
y_{i t}=\beta_{0}+\beta_{l} l_{i t}+\beta_{k} k_{i t}+\beta_{a} a g e_{i t}+\beta_{f} \hat{F}_{i t-1}+\delta_{j}+\delta_{t}+\omega_{i t}+\varepsilon_{i t},
$$

where $i$ and $t$ indicate firm and time respectively. Value added $\left(y_{i t}\right)$ is measured as the natural logarithm of net sales minus intermediate inputs; labor input $\left(l_{i t}\right)$ stands for the logarithm of 
the number of employees; and capital $\left(k_{i t}\right)$ is net of accumulated depreciation and calculated as the logarithm of the sum of tangible and intangible fixed assets minus goodwill; the degree of financial constraint $\left(\hat{F}_{i t-1}\right)$ is the measure calculated in section III; age it is the natural logarithm of the firm's age; and $\delta_{j}$ and $\delta_{t}$ are two-digit industry and year dummies. All variables are in real terms (see Appendix A for details). The error term has two components: a productivity term $\omega_{i t}$ known to the firm and correlated with the inputs, and a random productivity shock $\varepsilon_{i t}$. To estimate equation (5), we modify Levinsohn-Petrin algorithm and treat financial constraints as an additional state variable. ${ }^{17}$ As in Levinsohn and Petrin (2003), the coefficients of labor and plant characteristics are obtained in the first step using semiparametric techniques utilizing the variable materials to correct the simultaneity bias between labor and productivity. ${ }^{18}$ However, the materials' demand function now becomes a function of three state variables, capital, productivity and financial constraints, $m_{i t}=m_{i t}\left(k_{i t}, \omega_{i t}, \hat{F}_{i t-1}\right)$. Assuming monotonicity holds, we can invert the materials' demand function to obtain an expression for productivity depending on observable state variables, $\omega_{i t}=\omega_{i t}\left(m_{i t}, k_{i t}, \hat{F}_{i t-1}\right){ }^{19}$ Then, equation (5) can be rewritten in the following partially linear form:

$$
y_{i t}=\beta_{l} l_{i t}+\beta_{a} a g e_{i t}+\lambda_{t}\left(m_{i t}, k_{i t}, \hat{F}_{i t-1}\right)+\delta_{j}+\delta_{t}+\varepsilon_{i t},
$$

where

$$
\lambda_{t}\left(m_{i t}, k_{i t}, \hat{F}_{i t-1}\right)=\beta_{0}+\beta_{k} k_{i t}+\beta_{f} \hat{F}_{i t-1}+\omega_{i t}\left(m_{i t}, k_{i t}, \hat{F}_{i t-1}\right) .
$$

We use a third-order polynomial with a full set of interactions to approximate the unknown function $\lambda_{t}$, and estimate equation (6) using ordinary least squares (OLS). This gives us consistent coefficients on labor and other firm characteristics. In the second stage of the estimation algorithm, the probability that a firm exits from the Estonian registry is determined by the probability that the end-of-period productivity falls below an exit threshold. The same third-order polynomial in $m_{i t}, k_{i t}$, and $\hat{F}_{i t-1}$ of the first stage is used to estimate the surviving probability. In the final step, we estimate the coefficients on capital and financial constraints using nonlinear least squares. Year and two-digit industry dummies

\footnotetext{
${ }^{17}$ A similar approach is used in Fernandes (2007) who treats trade policy as a state variable. In our model, firms choose materials knowing the degree of financial constraint they faced at the end of the previous period, the current capital stock, and the current productivity level, including the part unobserved to the econometrician, $\omega_{i t}$.

${ }^{18}$ Alternatively, we could have followed Olley and Pakes (1996) and use investment as a proxy variable for productivity. However, given the substantial number of observations with zero or missing investment this would have resulted in a significant efficiency loss.

${ }^{19}$ In a similar setting, Van Biesebroeck (2005) discusses the conditions under which the monotonicity conditions hold for an investment function that includes the firm's export status as a state variable.
} 
are included as well and taken along the estimation procedure. Standard errors for the parameter estimates are obtained by bootstrapping. ${ }^{20}$

Since capital and financial constraints enter the function $\lambda_{t}($.$) twice, we need an additional$ identification assumption. We continue to assume that productivity follows a first-order Markov process, $\omega_{i t}=E\left(\omega_{i t} \mid \omega_{i t-1}\right)+\xi_{i t}$. Using this assumption, the identification condition for capital is that capital responds with a lag to productivity shocks. Therefore, we can identify the capital coefficient by using this condition:

$$
E\left[\varepsilon_{i t}+\xi_{i t} \mid k_{i t}\right]=0 .
$$

Because of the potential endogeneity, we include a lag of our measure of financial constraints. It is assumed that the financial constraints are observed by the firm in period $t-1$, similar to the assumption that plants choose their material input in period $t-1$ before productivity $\omega_{i t}$ is known. This means that investors may ration credit to firms based on their information set in $t-1$. Given that productivity follows a Markov process, the shock in period $t$ should be a surprise to investors, and, thus, $\hat{F}_{i t-1}$ should be uncorrelated with $\xi_{i t}$. Therefore, the following moment condition identifies the coefficient of financial constraints:

$$
E\left[\varepsilon_{i t}+\xi_{i t}\left|\hat{F}_{i t-1}\right|=0 .\right.
$$

\section{REsults}

\section{A. Baseline Results}

Table 7 presents our baseline results. To allow for variation in the impact of financial constraints on productivity, Equation (5) is estimated for each industry (defined at the onedigit level) separately. The dependent variable is the log form of real value added, and bootstrapped standard errors are reported in brackets. In contrast to our initial expectations, we find that financial constraints do not have an impact on firm-level productivity for most sectors. In particular, the last column of Table 7 shows that the coefficient on financial constraints is not significantly different from zero in eight out of ten sectors. Only in the sectors "construction" and "R\&D and other business activities" does the negative impact remain significant. A possible explanation for this result could be that firms in both sectors are heavily dependent on external finance for their operations. In particular, firms in the construction sector need capital to prefinance their projects since, in most cases, they will not have enough liquidity until the construction projects are finished and sold. Therefore, if firms

\footnotetext{
${ }^{20}$ The use of estimated regressors at different stages of the procedure increases the final coefficients' variability. Therefore, bootstrapped standard errors on the capital coefficient tend to be overestimated (Pakes and Olley, 1995). See Horowitz (2001) for an overview of the bootstrap estimation methodology.
} 
are unable to convince banks or investors that their projects are worthwhile, or if they cannot present sufficient collateral, they cannot undertake productivity-enhancing activities, with a detrimental effect on TFP relative to unconstrained firms. Similarly, firms in the R\&D sector need a continuous inflow of fresh capital to keep up with the latest technology and invest in frontier research. In general, this involves risky investment, and few banks and investors are willing to take this risk. Even the smallest constraint on obtaining adequate funding entails major consequences for the firm. This result is confirmed by a recent OECD study in which it is argued that the lack of appropriate financing has been a hindrance to the expansion of innovative (high-tech) SMEs in most OECD countries (OECD, 2006). The results on the R\&D sector are also in line with the findings of Aghion et al. (2007) who find negative shocks reduce R\&D investment and innovation more in firms that are credit constrained. Without special arrangements to finance $R \& D$ projects, the $R \& D$ sector will lack the necessary dynamism for employment creation and competitiveness, and positive spillovers to other sectors will be limited. Overall these results indicate that, although many Estonian firms may be subject to financial constraints, these have not resulted in significant differences in productivity levels.

\section{B. Robustness Checks}

In this section we discus the robustness of the key results reported above. Table 8 summarizes several tests and, to conserve space and emphasize key results, only reports the coefficient estimates for the financial constraints variable.

We begin by testing whether the firm size has any impact on the results. Previous studies have argued that failures in the investment climate have nonlinear effects on the employment growth across firm size categories (Aterido et al., 2007). To test whether there are nonlinear effects of financing constraints on productivity based on firm size, we divide the sample into micro firms (10 employees or less) and larger firms (keeping in mind that $96 \%$ of the firms in our sample have less than 50 employees). Those sectors for which we have too few observations in a particular size category are excluded from our analysis. Our results show that the negative effect in the "R\&D and other business activities" sector is driven by micro firms, whereas the negative effect in the construction sector comes from firms with more than 10 employees. Overall, however, productivity is not affected by financial constraints for most sectors independently of firm size.

Next we look whether the results are sensitive to the time period considered. In particular, we split the sample in two periods: column (3) only includes 1997 to 2000, while column (4) covers the period 2001-2005. These subperiods were chosen partly because the quality of data improves substantially after 2000. Besides, credit growth slowed sharply in the aftermath of the Russian crisis, and started recovering after 2000. Although there are hardly any differences across the two periods, the results indicate that financing constraints affected

productivity in the sector "construction" only in the period 1997-2000, whereas the effect on the sector "R\&D and other business activities" was only significant in the period 2001-2005. 
Next we explore the impact of sample selection and removing outliers. First, we include those firms with negative investment (column 5). Second, to control for possible outliers in our measure of liquidity constraints (column 6), we eliminate from each industry in our sample those firms above the $99^{\text {th }}$ percentile of the distribution of financial constraints. Finally, we examine whether modifying the financial constraint variable has any significant impact on the results (column 7). In particular, we estimate financial constraints by using a standard accelerator model of investment (as in Konings et al., 2003). This type of model links the demand for capital goods to the level or change in firm's output or sales, and has been used in the empirical literature extensively (see, for example, Abel and Blanchard, 1986; and Fazzari et al., 1988).

These robustness tests confirm our previous findings that financial constraints do not have a negative impact on productivity for most sectors. The results for the sector "R\&D and other business activities" are remarkably robust, suggesting that the negative impact of financial constraints on productivity was very large during the period 2000-05. The effect is slightly reduced, though, when using an alternative definition of financial constraints (column 7). On the other hand, the results on the construction sector are weak since the coefficient of financial constraints loses its significance in most of the robustness checks.

\section{Conclusions}

This paper provides new evidence on the link between finance and firm-level productivity, focusing on Estonia. We contribute to the literature in two important respects. First, we look explicitly at the role of financial constraints. For this purpose, we construct a measure that allows us to capture differences in the degree of financial constraint across firms and time. Second, we develop a methodology to estimate the impact of financial constraints on productivity that addresses some of the shortcomings of previous studies. In our estimation, we rely on production function estimates that correct for the simultaneity of input choices and exit.

Our results indicate that young and highly indebted firms tend to be more financially constrained. Overall, a large number of firms displays some degree of financial constraint, with firms in the primary sector the most constrained. More important, we find that financial constraints do not have an impact on productivity for most sectors. These results are robust to a variety of sensitivity checks.

What can explain these findings? There are a number of reasons why access to finance may not necessarily improve productivity for most sectors or the lack of it may not impair productivity. First, in the face or rapid credit growth, it is difficult for credit officers to screen clients and ensure that capital is allocated to the most productive activities (see, for example, Ghani and Suri, 1999). The rapid buildup in credit thus lowers the quality of investment and reduces the expected productivity gain. Second, higher liquidity may reduce the incentive of shareholders to undertake a costly monitoring of managers, which impedes efficient resource 
allocation and slows productivity growth (Shleifer and Vishny, 1986; and Bhide, 1993). Third, overinvestment and low productivity may also result when managers maximize their own utility rather than firm profits (Grabowski and Mueller, 1972). Finally, access to finance may increase firms' production capacity — for example, by expanding plant size — without necessarily increasing productivity (Power, 1998). All of these arguments indicate that financially unconstrained firms may not necessarily have higher productivity levels than constrained firms. In the absence of a more explicit estimation model, we cannot distinguish which of these channels is at play in Estonia. This is an area for future research.

In the current environment, when credit has seized up in many countries and many firms may confront financing constraints, our results may provide some hope. In particular, our findings suggest that productivity levels may not be lower than before or they may even increase if banks allocate credit more efficiently - toward more productive firms — or if credit is redirected toward productivity-enhancing projects rather than projects increasing production capacity. Obviously, this may not necessarily offset other negative factors dampening growth.

Our conclusions are, however, subject to some important caveats. First, firms are defined as being financially constrained if their investment is affected by their cash, after controlling for future expected profitability. Although this strategy has been widely used, there is an open debate on the accuracy of this definition. Second, the use of estimated regressors at different stages increases the final coefficients' variability. Therefore, bootstrapped standard errors on the financial constraints variable may be overestimated, resulting in the insignificance of the financial constraints variable for most sectors. In any case, the results in this paper provide a cautionary note, underscoring that the efficiency of credit allocation is what matters for productivity and output growth and that is not always a sure thing. 
Table 1. Ownership Structure 1/

\begin{tabular}{lrrr}
\hline & Private & State & Foreign \\
\hline Agriculture & 96 & 0 & 3 \\
Mining and quarrying & 88 & 0 & 12 \\
Manufacturing & 90 & 0 & 10 \\
Electricity, gas, and water & 59 & 40 & 1 \\
Construction & 97 & 0 & 2 \\
Business services & 92 & 1 & 7 \\
Public services & 94 & 3 & 3 \\
Total & 93 & 1 & 6 \\
\hline
\end{tabular}

Sources: Estonian Business Registry database; and authors' calculations.

1/ Percentage of total firms in each sector.

Table 2. Number of Firms by Year and Industry, 1997-2005

\begin{tabular}{|c|c|c|c|c|c|c|c|c|c|c|}
\hline Industry & 1997 & 1998 & 1999 & 2000 & 2001 & 2002 & 2003 & 2004 & 2005 & Total \\
\hline Agriculture & 516 & 542 & 538 & 599 & 677 & 777 & 829 & 878 & 805 & 6,161 \\
\hline Mining and quarrying & 31 & 29 & 31 & 34 & 42 & 47 & 49 & 47 & 51 & 361 \\
\hline Manufacturing & 1,377 & 1,605 & 1,881 & 2,205 & 2,508 & 2,728 & 3,000 & 3,127 & 3,063 & 21,494 \\
\hline Electricity, gas, and water & 98 & 133 & 138 & 136 & 142 & 153 & 155 & 158 & 153 & 1,266 \\
\hline Construction & 714 & 892 & 937 & 1,110 & 1,303 & 1,488 & 1,694 & 1,988 & 2,287 & 12,413 \\
\hline Business services & 4,844 & 5,976 & 6,662 & 8,092 & 9,206 & 10,132 & 10,708 & 11,421 & 11,376 & 78,417 \\
\hline Public services & 352 & 505 & 603 & 719 & 874 & 1,029 & 1,184 & 1,272 & 1,327 & 7,865 \\
\hline Total & 7,932 & 9,682 & 10,790 & 12,895 & 14,752 & 16,354 & 17,619 & 18,891 & 19,062 & 127,977 \\
\hline
\end{tabular}

Sources: Estonian Business Registry database; and authors' calculations.

Table 3. Summary Statistics

\begin{tabular}{lcc}
\hline & Debt & No Debt \\
\hline Percentage of firms & 46 & 54 \\
Number of employees & 22.9 & 7.2 \\
Age & 6.1 & 5.1 \\
Sales & $17,200,000$ & $4,664,333$ \\
Value added & $5,247,111$ & $1,338,731$ \\
Capital intensity & 198,266 & 59,341 \\
Labor productivity & 242,770 & 192,349 \\
Labor productivity growth & 0.06 & 0.04 \\
Investment ratio & 0.12 & 0.05 \\
\hline
\end{tabular}

Sources: Estonian Business Registry database; and authors' calculations.

Notes: Firms are divided in two groups: firms with long-term liabilities (Debt) and firms with no long-term liabilities on their balance sheets during their entire lifespan (No debt). All variables are measured in Estonian Krooni and deflated by two-digit sector deflators; all variable definitions can be found in Appendix A. Capital intensity is defined as (net real tangible + net real intangible assets - goodwill) / labor; labor productivity = real value added per worker; and investment ratio = real investment/real total assets lagged one year. 


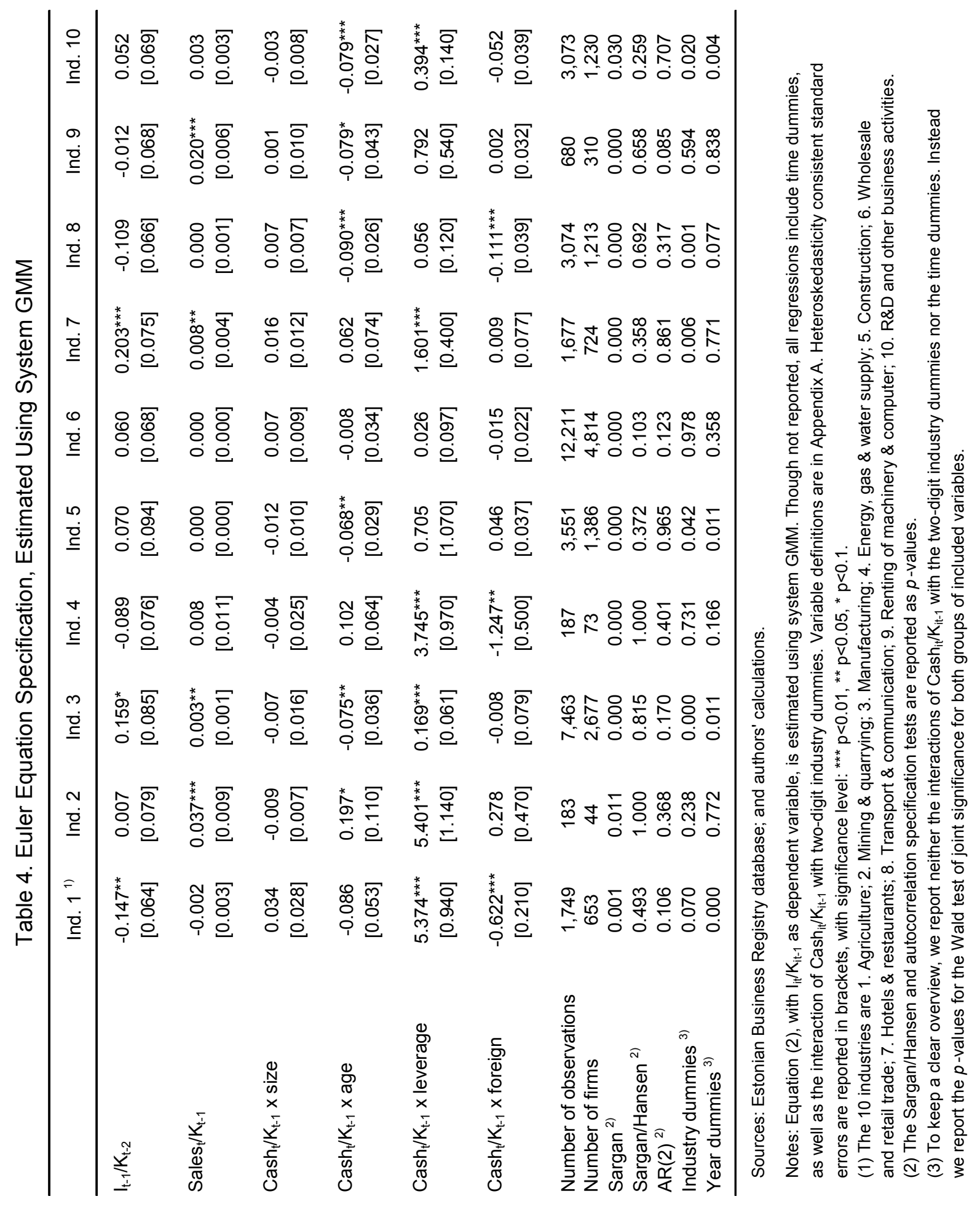


Table 5. Magnitude and Distribution of Financing Constraints by Sector

\begin{tabular}{|c|c|c|c|c|c|}
\hline \multirow[b]{2}{*}{ Industry } & \multicolumn{2}{|c|}{ Number of Observations } & \multicolumn{3}{|c|}{ Financing Constraints } \\
\hline & Total & $\begin{array}{c}\text { Zero } \\
\text { constraints }\end{array}$ & Mean & Median & $\begin{array}{l}\text { Standard } \\
\text { deviation }\end{array}$ \\
\hline 1 Agriculture & 5,369 & 286 & 1.035 & 0.482 & 1.441 \\
\hline 2 Mining and quarrying & 342 & 110 & 0.415 & 0.037 & 0.839 \\
\hline 3 Manufacturing & 19,346 & 3,046 & 0.093 & 0.066 & 0.106 \\
\hline 4 Electricity, gas and water supply & 550 & 67 & 0.456 & 0.083 & 0.714 \\
\hline 5 Construction & 11,001 & 1,034 & 0.099 & 0.055 & 0.142 \\
\hline 6 Wholesale and retail trade & 36,836 & 76 & 0.031 & 0.031 & 0.013 \\
\hline 7 Hotels and restaurants & 5,296 & 831 & 0.304 & 0.046 & 1.117 \\
\hline 8 Transport and communication & 9,547 & 649 & 0.090 & 0.070 & 0.081 \\
\hline 9 Renting of machinery and computer activities & 2,413 & 290 & 0.121 & 0.054 & 0.266 \\
\hline $10 \mathrm{R} \& D$ and other business activities & 9,819 & 733 & 0.094 & 0.064 & 0.112 \\
\hline
\end{tabular}

Sources: Estonian Business Registry database; and authors' calculations.

Note: Financial constraints are calculated based on equation (3).

Table 6. Correlation between Financial Constraints and Other Firm Characteristics

\begin{tabular}{lccccc}
\hline & $\begin{array}{c}\text { Financial } \\
\text { Constraints }\end{array}$ & $\begin{array}{c}\text { Value } \\
\text { Added }\end{array}$ & $\begin{array}{c}\text { Sales per } \\
\text { Worker }\end{array}$ & $\begin{array}{c}\text { Labor } \\
\text { Productivity }\end{array}$ & TFP \\
\hline Financial constraints & 1.000 & $\ldots$ & $\ldots$ & $\ldots$ & $\ldots$ \\
Value added & -0.411 & 1.000 & $\ldots$ & $\ldots$ & $\ldots$ \\
Sales/worker & -0.879 & 0.327 & 1.000 & $\ldots$ & $\ldots$ \\
Labor productivity & -0.477 & 0.387 & 0.428 & 1.000 & $\ldots$ \\
TFP & -0.840 & 0.074 & 0.659 & 0.396 & 1.000 \\
\hline
\end{tabular}

Sources: Estonian Business Registry database; and authors' calculations.

Notes: Spearman's rank correlations are based on the industry means to abstract from industry-specific

effects. Financial constraints are calculated based on equation (3). Labor productivity is measured as real value added per worker. Other variable definitions are in Appendix A. 
Table 7. Baseline Results, by Industry

\begin{tabular}{lrrrrr}
\hline & $\begin{array}{c}\text { Number of } \\
\text { Observations }\end{array}$ & Labor & Capital & Age & Score \\
& & & & & \\
\hline Agriculture & 1,825 & $0.505^{* * *}$ & $0.335^{* * *}$ & $-0.019^{* * *}$ & 0.008 \\
Mining and quarrying & & {$[0.042]$} & $0.070]$ & {$[0.010]$} & {$[0.018]$} \\
& 189 & $0.340^{* * *}$ & $0.322^{* * *}$ & 0.031 & 0.059 \\
Manufacturing & & {$[0.135]$} & $0.127]$ & {$[0.050]$} & {$[0.068]$} \\
& 7,798 & $0.586^{* * *}$ & $0.051^{* * *}$ & $-0.014^{* * *}$ & 0.018 \\
Electricity, gas, and water supply & & {$[0.017]$} & $0.026]$ & {$[0.005]$} & {$[0.124]$} \\
Construction & 196 & $0.481^{* * *}$ & 0.203 & -0.003 & -0.001 \\
Wholesale and retail trade & & {$[0.110]$} & $0.188]$ & {$[0.027]$} & {$[0.135]$} \\
Hotels and restaurants & 3,756 & $0.643^{* * *}$ & $0.190^{* * *}$ & $-0.024^{* * *}$ & $-0.299^{*}$ \\
& & {$[0.030]$} & $0.035]$ & {$[0.006]$} & {$[0.156]$} \\
Transport and communication & 12,714 & $0.520^{* * *}$ & $-0.022^{* * *}$ & $-0.012^{* * *}$ & 0.05 \\
Renting of machinery and computer activities & & {$[0.017]$} & $0.011]$ & {$[0.003]$} & {$[0.120]$} \\
R\&D and other business activities & 1,782 & $0.720^{* * *}$ & 0.039 & $-0.035^{* * *}$ & -0.009 \\
& & {$[0.043]$} & $0.090]$ & V0.007] & {$[0.023]$} \\
\hline & 3,201 & $0.567^{* * *}$ & $0.214^{* * *}$ & $-0.061^{* * *}$ & 0.336 \\
& & {$[0.035]$} & $0.053]$ & {$[0.013]$} & {$[0.410]$} \\
\hline
\end{tabular}

Sources: Estonian Business Registry database; and authors' calculations.

Notes: The dependent variable is the log form of real value added, and we use bootstrapping methods (1,000 replications) to obtain correct standard errors (reported in brackets). Equation (5) is estimated for each one-digit industry separately. $R$-squared statistics are not available for the modified Levinsohn-Petrin estimation. Though not reported, all regressions include two-digit industry dummies and time dummies. Significance level: ${ }^{* *} p<0.01,{ }^{* *} p<0.05,{ }^{*} p<0.1$. Variable definitions are in Appendix A. 


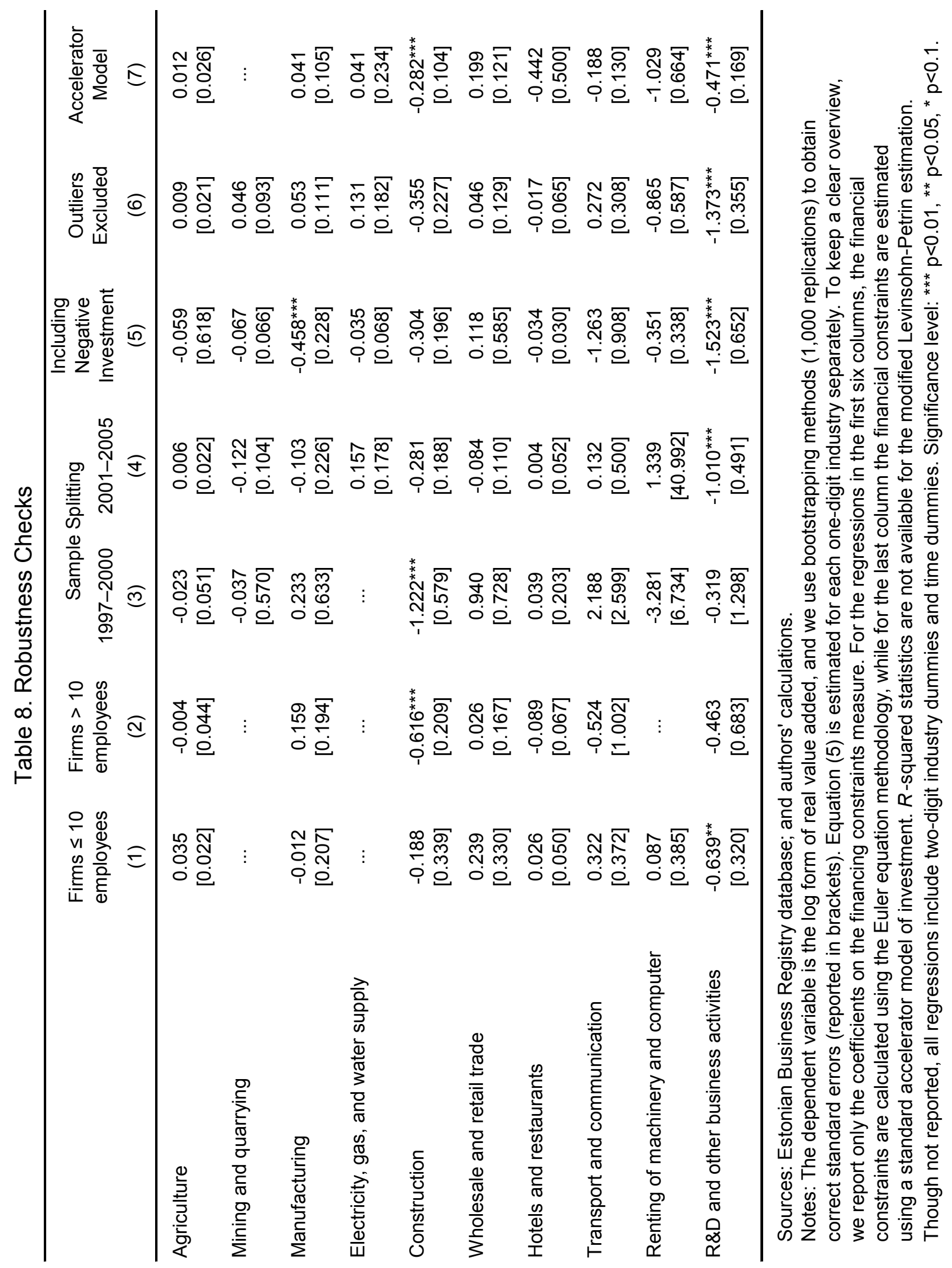


Figure 1. Size Distribution

(In terms of average number of employees in a firm)

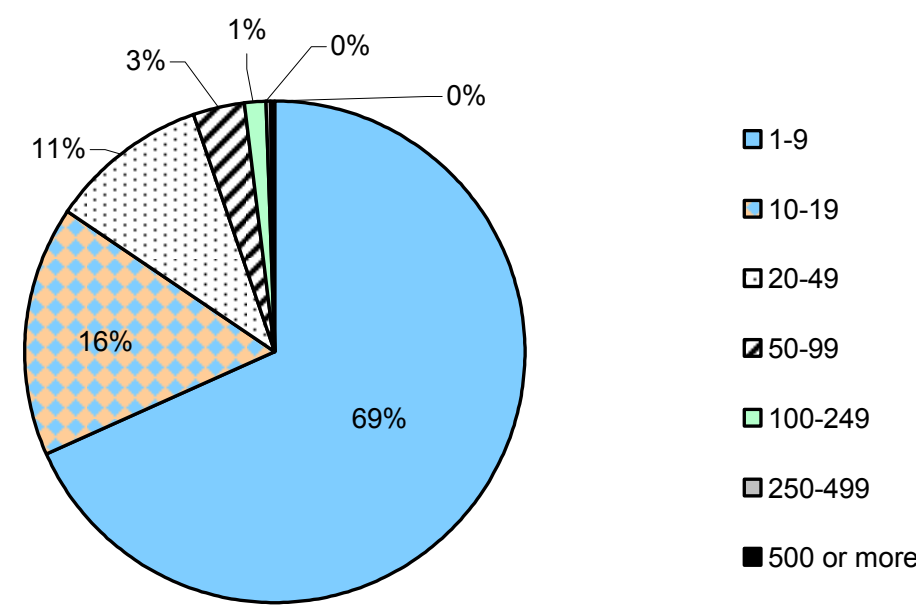

Sources: Estonian Business Registry; and authors' calculations.

Figure 2. Entry and Exit Rates, 1997-2005

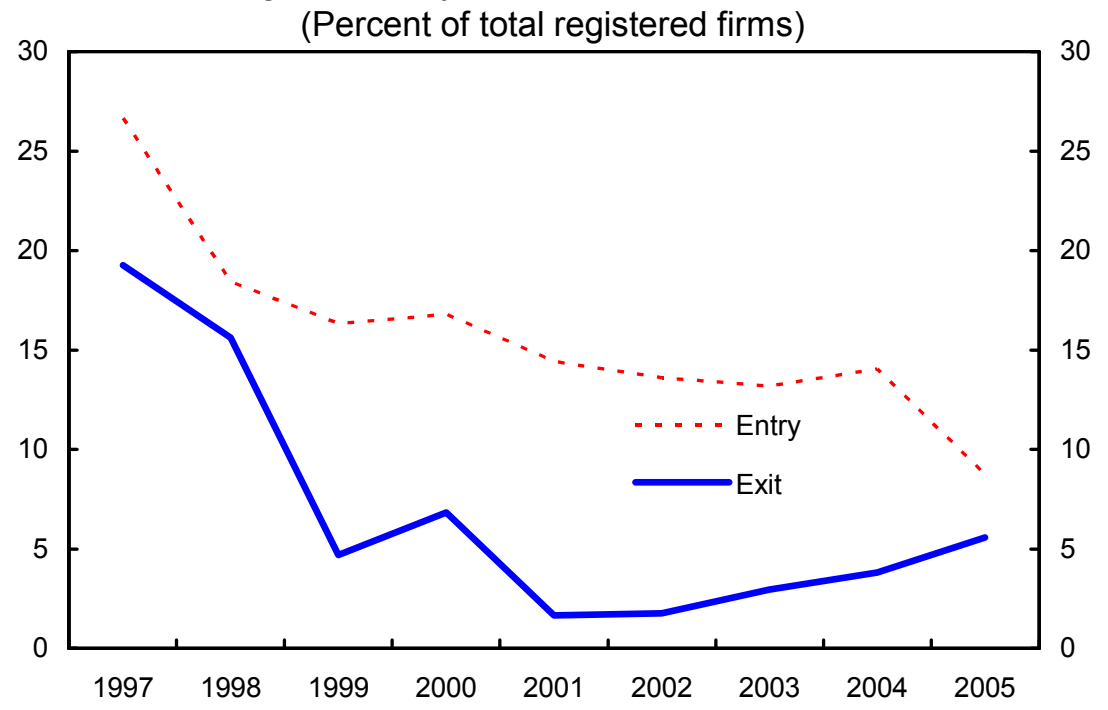

Sources: Estonian Business Registry database; and authors' calculations. 
Figure 3. Sales per worker, 1997-2005

(thousands of Estonian krooni)

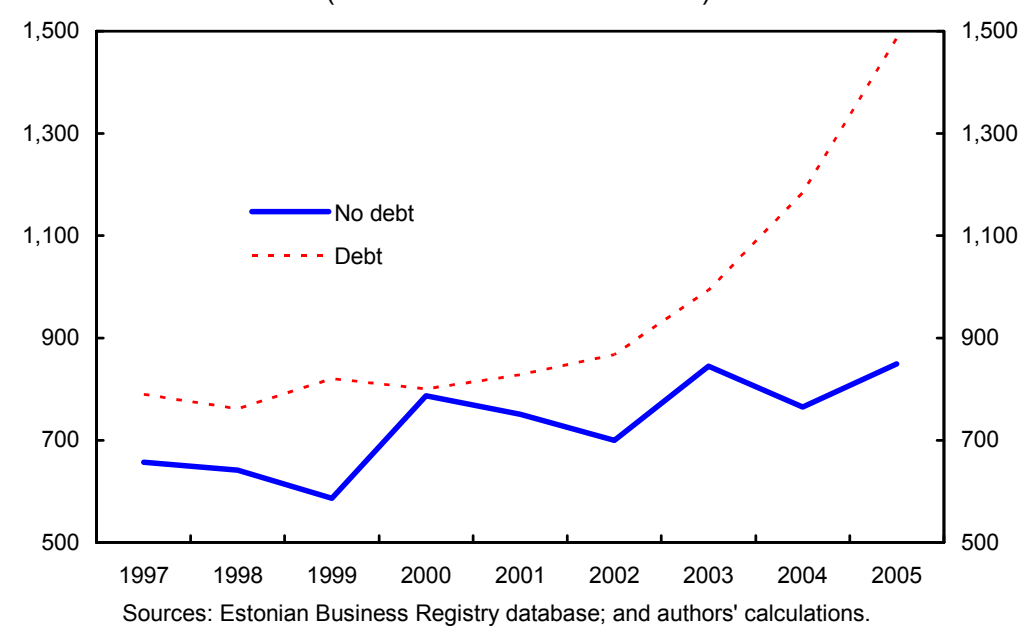

Figure 4. Capital Intensity, 1997-2005

(Capital per worker, thousand of Estonian krooni)

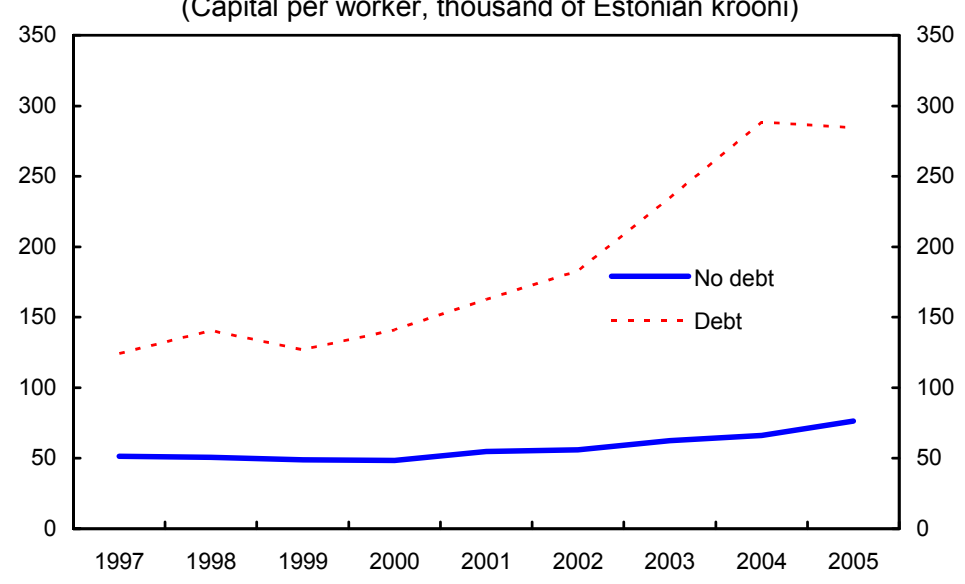

Sources: Estonian Business Registry database; and authors' calculations.

Figure 5. Investment Ratio, 1997-2005

(Investment at $t$ divided by total assets at $t-1$ )

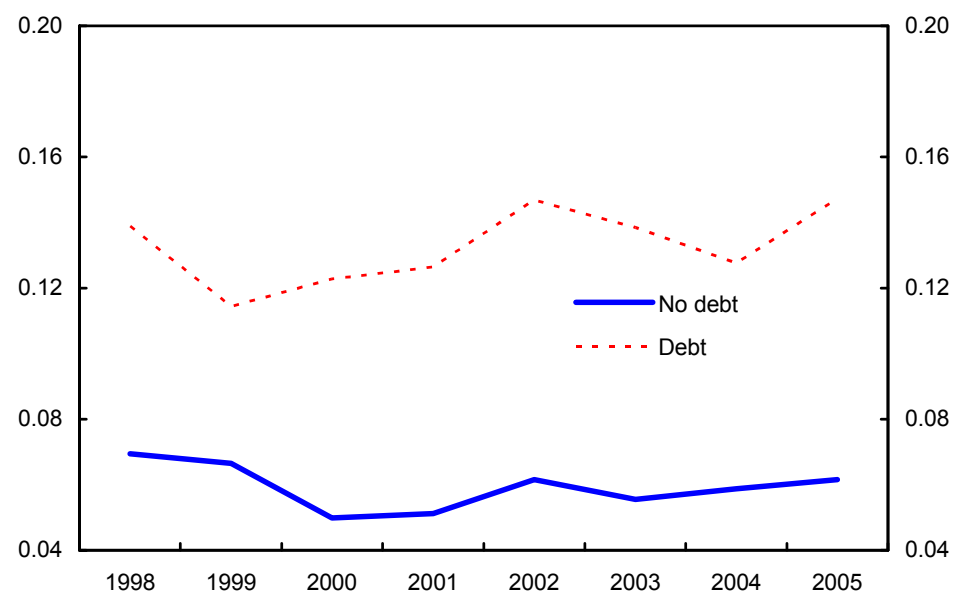

Sources: Estonian Business Registry database; and authors' calculations. 
Figure 6. Mean Financial Constraints by Industry, 1998-2005 1/

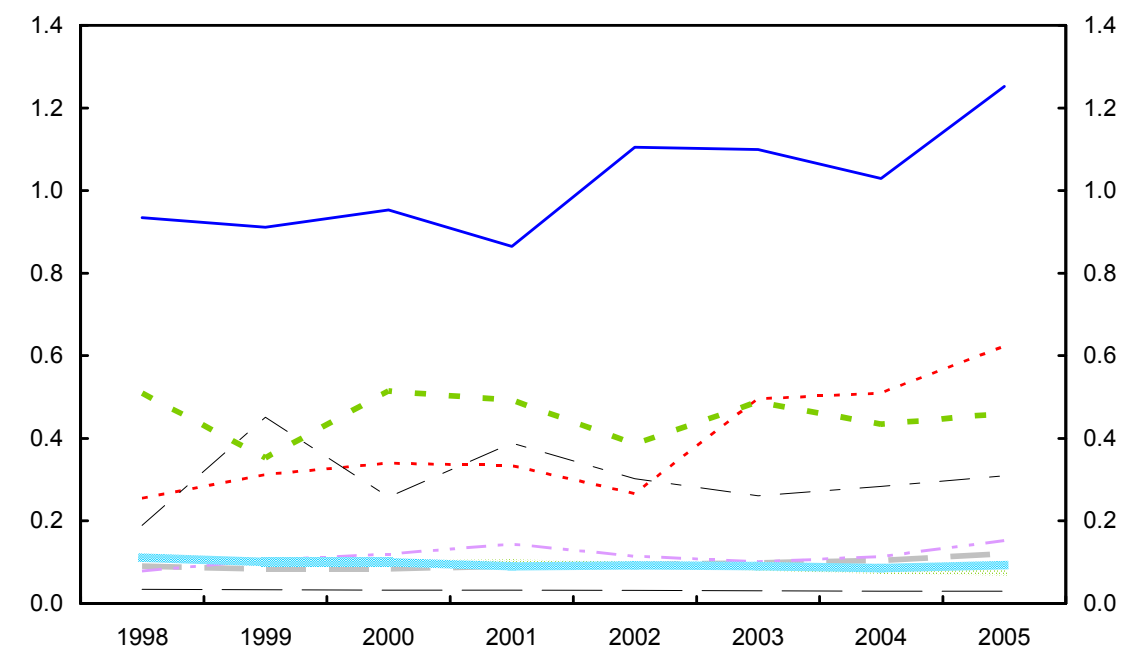

1.4

1.2

1.0

- - - - Mining and quarrying

- Manufacturing

- - Electricity, gas, water

- Construction

Wholesale, retail trade

- Hotels, restaurants

Transport, communication

- - - Machinery, computers

Research, business activities

Sources: Estonian Business Registry database; and authors' calculations.

1/ Financial constraints are calculated based on equation (3). 


\section{Appendix A. Data Sources And Definitions}

The data used in this paper come from the Estonian Business Registry and cover the period 1995-2005. Due to missing information on employment for the years 1995-96, we use data only from 1997. The number of firms in the data set increases over time, partly due to an improvement in the coverage. The improvement in data coverage may be related to the introduction in 2000 of fines penalizing those firms that do not submit income or balance sheet statements. In order to create our sample, we follow several steps:

1. We construct a longitudinal panel using registration codes. Several corrections are made to take into account the change in registration codes: (i) firms that change registration codes because of the transfer from the enterprise registry to the business registry are considered the same firm; (ii) in case of acquisitions, the acquiring and acquired firms are considered a unique firm for the whole sample period; and (iii) for all other transactions (mergers, breakup, and divesture), we treat firms involved before and after the transaction as different.

2. For 46 percent of the registered firms, either we have no data on the variables used in the analysis, or there is no clear information about the industry to which they belong. These firms are excluded.

3. In addition, we exclude unrealistic observations for the variables used in the estimation. In particular, we exclude individual observations where employment, capital, and intermediate inputs are zero or negative (23 firms).

4. During the analysis we noticed that some outliers were influencing to an important extent our results. After checking the data, we realized that these outliers were probably the result of input mistakes, poor data quality, mergers and acquisitions, divestments, or revaluations of capital. Therefore we imposed two outlier rules to exclude observations with extreme values: (i) we deleted the top-five percentile observations of capital growth, and (ii) we deleted the top-one percentile observations of the cash stock-to-capital ratio.

5. We exclude the sectors with EMTAK (Classification of Economic Activities of Estonia) 65 to 70 ("financial intermediation" and "real estate activities") and EMTAK 75 to 99 ("public services"). Firms in these sectors are not or less subject to financial constraints, or their investment behavior depends more on political decisions or economic policy rather than on access to external finance.

6. Additionally, state-owned firms are more likely to face soft budget constraints, and are not necessarily profit-maximizing agents. Since these characteristics may distort the analysis, we decided to exclude the state-owned firms from our analysis (210 firms).

7. Finally, we do not observe a firm's investment expenditure directly, but derive it from the law of motion of capital. As a consequence, we cannot discern investment expenditure from the sales of capital goods; we have only a figure for the net investment of a firm. To minimize this problem, we exclude observations with negative investment ( 5 percent of the observations). 
All variables used in this paper are in real terms. Sales, value added, and cash are deflated by the output deflator; intermediate inputs are deflated by the intermediate inputs deflator; assets, debt, and investment are deflated with the gross capital formation price index. All deflators come from the system of national accounts provided by the Statistical Office of Estonia, and are available for 16 sectors (corresponding to the one-digit International Standard Industrial Classification (ISIC Rev. 3.1). The following variables are used:

- Sales $\left(\right.$ Sales $\left._{i t}\right)$ : net revenue received from the sale of products, goods and services.

- $\quad$ Labor $\left(L_{i t}\right)$ : number of employees.

- Intermediate inputs $\left(M_{i t}\right)$ : cost of goods, raw materials, and services purchased for core activities.

- Value added $\left(Y_{i t}\right)$ : net sales minus intermediate inputs.

- Capital $\left(K_{i t}\right)$ : tangible and intangible fixed assets minus the goodwill, net of accumulated depreciation.

- Investment $\left(I_{i t}\right)$ : calculated based on data on capital and depreciation, $I_{i t}=K_{i t}-K_{i t-1}+D_{i t}$, where $D_{i t}$ stands for reported annual depreciation. Due to this calculation, we have no data on investment for the first year of a firm's observation series.

- Cash stock $\left(\mathrm{Cash}_{i t}\right)$ : sum of the cash stock and short-term financial securities, such as shares at the beginning of period $t$.

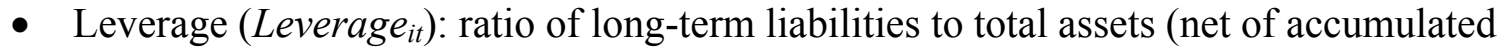
depreciation) at the beginning of period $t$.

- Age $\left(A g e_{i t}\right)$ : age of the firm at the beginning of period $t$, based on the entry date in the registry.

- $\quad$ Size $\left(\right.$ Size $\left._{i t}\right)$ : continuous measure of firm size, measured by total assets (net of accumulated depreciation) at the beginning of period $t$;

- Owner $\left(\right.$ Owner $\left._{i t}\right)$ : either private, state, foreign or other. Shareholders with more than 10 percent of share capital of the firm shall be disclosed, and upon this information the Statistical Office of Estonia classifies the ownership type. For example, a firm is labeled foreign if the sum of the foreign-owned shares surpasses 50 percent.

- Industry classification: Estonian EMTAK code (Classification of Economic Activities of Estonia).

Table A.1 provides an overview of the classification of industries used in Estonia. The total number of observations and the number of firms are listed in columns 2 and 3. 
Table A1. Industry Classification

\begin{tabular}{|c|c|c|c|}
\hline Code & Sector Name & $\begin{array}{l}\text { Number of } \\
\text { Observations }\end{array}$ & $\begin{array}{l}\text { Number of } \\
\text { Firms }\end{array}$ \\
\hline 1 & Agriculture, hunting, and related service activities & 3,138 & 880 \\
\hline 2 & Forestry, logging, and related service activities & 1,722 & 595 \\
\hline 5 & Fishing, fish farming, and related service activities & 509 & 140 \\
\hline $10-14$ & Mining and quarrying & 342 & 59 \\
\hline $15-16$ & Manufacture of food products and beverages, and tobacco products & 1,965 & 494 \\
\hline 17 & Manufacture of textiles & 812 & 187 \\
\hline $18-19$ & Manufacture of wearing apparel, tanning, dressing, and dyeing & 1,969 & 469 \\
\hline 20 & Manufacture of wood and straw products, except furniture & 3,687 & 1,014 \\
\hline $21-22$ & Manufacture of pulp, paper, and publishing and printing & 1,896 & 472 \\
\hline 23-24 & Manufacture of coke, refined petroleum products, nuclear fuel, and chemicals & 379 & 105 \\
\hline 25 & Manufacture of rubber and plastic products & 662 & 165 \\
\hline 26 & Manufacture of other nonmetallic mineral products & 613 & 165 \\
\hline $27-28$ & Manufacture of basic metals and fabricated metal products & 2,707 & 732 \\
\hline 29 & Manufacture of machinery and equipment not elsewhere classified & 909 & 231 \\
\hline $30-32$ & $\begin{array}{l}\text { Manufacture of office and electrical machinery, computers, televisions, and } \\
\text { radio transmitters }\end{array}$ & 732 & 175 \\
\hline 33 & $\begin{array}{l}\text { Manufacture of medical, precision and optical instruments, watches, and } \\
\text { clocks }\end{array}$ & 526 & 114 \\
\hline 35 & Manufacture of transport equipment & 442 & 131 \\
\hline $36-37$ & Manufacture not elsewhere classified & 2,047 & 556 \\
\hline $40-41$ & $\begin{array}{l}\text { Electricity, gas, steam and hot water supply, and collection, purification, and } \\
\text { distribution of water }\end{array}$ & 550 & 147 \\
\hline 45 & Construction & 11,001 & 3,428 \\
\hline 50 & $\begin{array}{l}\text { Sale, maintenance, and repair of motor vehicles and motorcycles, and retail } \\
\text { sale of automotive fuel }\end{array}$ & 5,856 & 1,631 \\
\hline 51 & $\begin{array}{l}\text { Wholesale trade and commission trade, except of motor vehicles and } \\
\text { motorcycles }\end{array}$ & 14,720 & 4,561 \\
\hline 52 & $\begin{array}{l}\text { Retail trade, except of motor vehicles and motorcycles, and repair of personal } \\
\text { and household goods }\end{array}$ & 16,260 & 4,449 \\
\hline 55 & Hotels and restaurants & 5,296 & 1,560 \\
\hline $60-62$ & Land, water, and air transport & 6,680 & 1,917 \\
\hline 63 & Supporting and auxiliary transport activities, and activities of travel agencies & 2,499 & 820 \\
\hline 64 & Post and telecommunications & 368 & 125 \\
\hline $65-67$ & Financial intermediation & 416 & 197 \\
\hline 70 & Real estate activities & 3,902 & 1,428 \\
\hline 71 & $\begin{array}{l}\text { Renting of machinery and equipment without operator and of personal and } \\
\text { household goods }\end{array}$ & 821 & 307 \\
\hline 72 & Computer and related activities & 1,592 & 530 \\
\hline $73-74$ & Research and development, and other business activities & 9,819 & 3,192 \\
\hline 80 & Public administration and defense, compulsory social security, and education & 926 & 281 \\
\hline 85 & Health and social work & 2,728 & 714 \\
\hline 90 & Sewage and refuse disposal, sanitation, and similar activities & 395 & 115 \\
\hline 92 & Recreational, cultural, and sporting activities & 1,264 & 425 \\
\hline \multirow[t]{2}{*}{$91-93$} & Other service activities & 1,630 & 516 \\
\hline & Total & 111,780 & 33,027 \\
\hline
\end{tabular}

Source: Estonian Business Registry database. 


\section{APPENDIX B. EULER EQUATION SPECIFICATION}

The derivation of the Euler model of investment follows closely Forbes (2007), Laeven (2003), Love (2003), and Harrison et al. (2004), all of which build on Bond and Meghir (1994). We refer to Love (2003) in specific for a more in-depth discussion of the Euler equation specification, and for proofs of the underlying derivations.

To start, assume that each firm maximizes its present discounted value of current and future net cash flows, subject to the capital accumulation and external financing constraints. The firm's market value is given by

$$
V_{t}\left(K_{t}, \xi_{t}\right)=\max _{\left\{I_{t+s}\right\}_{s=0}^{\infty}} D_{t}+E_{t}\left[\sum_{s=1}^{\infty} \beta_{t+s-1} D_{t+s}\right],
$$

subject to

$$
\begin{aligned}
& D_{t}=\Pi\left(K_{t}, \xi_{t}\right)-C\left(I_{t}, K_{t}\right)-I_{t}, \\
& K_{t+1}=(1-\delta) K_{t}+I_{t}, \\
& D_{t} \geq 0 .
\end{aligned}
$$

The first constraint (B.2) is the dividend paid to shareholders at the start of period $t$, the second constraint (B.3) is the capital stock accounting identity, and the third constraint (B.4) states that dividends $\left(D_{t}\right)$ must be nonnegative. $\Pi\left(K_{t}, \xi_{t}\right)$ is the restricted profit function (i.e., already maximized with respect to variable costs), with $K_{t}$ the capital stock at time $t$ and $\xi_{t}$ being a productivity shock. $C\left(I_{t}, K_{t}\right)$ is the adjustment cost function, $I_{t}$ is investment expenditure, $\delta$ is the depreciation rate of capital, and $\beta_{t+s-1}$ represents a discount factor.

Financial frictions are introduced via a nonnegativity constraint on dividends (B.4), and the multiplier for this constraint is denoted as $\lambda_{t}$. This multiplier can be interpreted as the shadow cost associated with raising new equity, and implies that external financing is costly due to information or contracting costs. Rearranging the first-order conditions to the above maximization problem yields the Euler equation:

$$
1+\left(\frac{\partial C}{\partial I}\right)_{t}=\beta_{t} E_{t}\left[\Theta_{t}\left\{\left(\frac{\partial \Pi}{\partial K}\right)_{t+1}+(1-\delta)\left(1+\left(\frac{\partial C}{\partial I}\right)_{t+1}\right)\right\}\right],
$$

where $\partial C / \partial I$ is the marginal adjustment cost of investment, and $\partial \Pi / \partial K$ is the marginal profit of capital (i.e., the contribution of an extra unit of capital to the firm's profits, referred to below as $\left.M P K_{t}\right)$. In the Euler equation, the factor $\Theta_{t}=\left(1+\lambda_{t+1} / 1+\lambda_{t}\right)$ is the relative shadow cost of external finance in period $t+1$ versus period $t$. In perfect capital markets, $\left(\lambda_{t+1}=\lambda_{t}=0\right)$ applies. Thus, a firm is "financially constrained" if the shadow cost of external funds today is higher than tomorrow $\left(1+\lambda_{t+1} / 1+\lambda_{t}\right)<1$.

In order to obtain an empirical model of investment that will allow us to estimate equation (B.5), we need to parameterize the model. First, we proxy the (degree) of financing constraints $\Theta_{t}$ by the stock of liquid assets at the start of period $t$. Cash stock (or cash flow) has an intuitive interpretation as money that is available for investment when the opportunity 
presents itself.

$$
\Theta_{i t}=a_{0 i}+a\left(\frac{\text { Cash }}{K}\right)_{i t}
$$

Next, the marginal profitability of capital, $M P K_{t}$, can be derived from a profit maximization problem as a function of sales to capital ratio, $M P K_{i t}=\theta_{i}(\text { Sales } / K)_{i t}$, where $\theta=\alpha_{k} / \mu$ is the ratio of the capital share of output from a Cobb-Douglas production function $\left(\alpha_{k}\right)$, and a markup $(\mu) .{ }^{21}$ The firm-specific parameter $\theta_{i}$ is empirically captured by the firm fixed effects using the following approximation

$$
M P K_{i t}=\theta_{i}\left(\frac{\text { Sales }}{K}\right)_{i t} \approx \text { const. }+\theta_{i}+\bar{\theta}\left(\frac{\text { Sales }}{K}\right)_{i t},
$$

where $\bar{\theta}$ can be thought of as the industry average.

Also, assuming a quadratic adjustment cost function that is linearly homogenous in investment and capital, the marginal adjustment cost of investment can be written as

$$
\left(\frac{\partial C}{\partial I}\right)_{t}=\frac{1}{\alpha_{1}}\left[\left(\frac{I}{K}\right)_{t}-\alpha_{2}\left(\frac{I}{K}\right)_{t-1}-\alpha_{i}+\alpha_{t}\right],
$$

where $\alpha_{1}$ and $\alpha_{2}$ are constants, $\alpha_{i}$ is a firm-specific level of investment at which adjustment costs are minimized, and $\alpha_{t}$ are time-specific effects.

Finally, to simplify the estimation and interpretation of the coefficients, we linearize the Euler equation using a first-order Taylor approximation around the means. By assuming rational expectations and substituting equations (B.6), (B.7), and (B.8) into equation (B.5), the presence of financing constraints can be tested through the following empirical specification of the Euler equation:

$$
\left(\frac{I}{K}\right)_{i t}=\theta_{0}+\theta_{1}\left(\frac{I}{K}\right)_{i t-1}+\theta_{2}\left(\frac{\text { Sales }}{K}\right)_{i t}+\theta_{3}\left(\frac{\text { Cash }}{K}\right)_{i t}+\alpha_{i}+\delta_{t}+\varepsilon_{i t},
$$

where $\alpha_{i}$ captures firm-specific parameters in the adjustment cost function and the $M P K$, plus the average firm-specific level of financing constraints and the price of investment goods. $\delta_{t}$ denotes time dummies. A firm is considered to be more financially constrained if the cash coefficient, $\theta_{3}$, is estimated to be more positive.

\footnotetext{
${ }^{21}$ Gilchrist and Himmelberg (1999) provide a proof for this derivation.
} 


\section{Appendix C. Estimating Total Factor Productivity}

Although a full description of TFP estimation based on Olley and Pakes (1996) and Levinsohn and Petrin (2003) is beyond the scope of this paper, the steps implemented are briefly outlined below.

We assume that firms maximize the expected value of both current and future profits from a Cobb-Douglas production function under uncertainty:

$$
y_{i t}=\beta_{0}+\beta_{l} l_{i t}+\beta_{k} k_{i t}+\omega_{i t}+\varepsilon_{i t}
$$

where $i$ and $t$ indicate firm and time, respectively. $y_{i t}$ represents the natural logarithm of value added, and $l_{i t}$ and $k_{i t}$ stand for the logs of labor and capital, respectively. The firm-specific error term consists of two parts: firm productivity, $\omega_{i t}$, which is observed by the firm but not by the econometrician, and $\varepsilon_{i t}$, which are unpredictable zero-mean shocks to productivity after inputs are chosen. This asymmetric information about $\omega_{i t}$ causes two biases in the OLS estimates: a simultaneity bias and a selection bias. The endogeneity bias stems from the correlation between unobserved productivity and a plant's input decisions. If more productive plants tend to hire more workers due to higher current and anticipated future profitability, OLS will tend to provide upwardly biased estimates on the input coefficients. The selection bias arises because firms with larger capital stocks can expect larger future returns for any given level of current productivity, and will therefore continue in operation for lower productivity levels, thereby leading to a negative bias in the OLS capital coefficient.

To address these biases, Olley and Pakes (1996) developed a semiparametric approach in which they use capital and investment as a proxy for unobserved productivity. Levinsohn and Petrin (2003) suggest a modification of the Olley-Pakes approach by using intermediate inputs (raw materials, electricity, or fuels) instead of investment. The data coverage of the proxy is an important factor in deciding which approach to use, ${ }^{22}$ since plants with zero or missing observations would be systematically dropped from the estimation, with a significant loss in efficiency as result. ${ }^{23}$ Taking into account the data availability in our Estonian data, we choose to use the Levinsohn-Petrin intermediate inputs proxy estimator.

The timing of decisions of firm $i$ in industry $j$ in year $t$ is as follows. A firm initially observes its productivity, $\omega_{i t}$, which is assumed to evolve according to an exogenous Markov process. Then, in deciding whether to exit or not, the firm chooses the input variables labor and materials, and how much to invest in capital. A firm's input demand function depends on capital and on privately known productivity, $m_{i t}=m_{i t}\left(k_{i t}, \omega_{i t}\right)$. Assuming that $m_{i t}$ is strictly increasing in $\omega_{i t}$ (monotonicity condition), we can invert the materials' demand function to

\footnotetext{
${ }^{22}$ Other differences are related to the underlying assumptions and estimation techniques. See Ackerberg et al. (2005) for a review and detailed discussion of the Olley-Pakes and Levinsohn-Petrin methodologies.

${ }^{23}$ About 45 percent of the total number of observations in our dataset has zero or missing investment, whereas most firms report positive use of materials in each year.
} 
obtain an expression for productivity depending on observable variables:

$$
\omega_{i t}=m_{t}^{-1}\left(m_{i t}, k_{i t}\right)=\phi_{t}\left(m_{i t}, k_{i t}\right) .
$$

Substituting (C.2) into (C.1) yields the first stage of the estimation procedure

$$
y_{i t}=\beta_{l} l_{i t}+\lambda_{t}\left(m_{i t}, k_{i t}\right)+\varepsilon_{i t},
$$

where

$$
\lambda_{t}\left(m_{i t}, k_{i t}\right)=\beta_{0}+\beta_{k} k_{i t}+\phi_{t}\left(m_{i t}, k_{i t}\right)
$$

The functional form of $\lambda_{t}$ is not known, but can be approximated by a third-order polynomial series in $m_{i t}$ and $k_{i t}{ }^{24}$ The estimation of the partially linear model in (C.3) yields consistent estimates for the labor coefficient. Since $k_{i t}$ is collinear with the non-parametric function, we can not identify $\beta_{k}$. In order to consistently estimate the capital coefficient, the effect of capital on output still needs to be separated from its effect on a plant's materials demand.

Since Levinsohn and Petrin (2003) do not incorporate the survival probability, we follow Olley-Pakes' approach for the second stage. The probability that a firm exits from the sample is determined by the probability that the end-of-period productivity falls below an exit threshold. We generate an estimate of the survival probability by running a probit regression on the same third-order polynomial defined as before; the estimated survival probability is denoted by $\Pi_{i t}$.

The final step is to estimate $\beta_{k}$ from the resulting equation:

$$
y_{i t}-\hat{\beta}_{l} l_{i t}=\beta_{k} k_{i t}+g\left(\Pi_{i t-1}, \hat{\lambda}_{t-1}-\beta_{k} k_{i t-1}\right)+\eta_{i t},
$$

where $\hat{\beta}_{l}$ is the estimate for $\beta_{l}$ out of the first stage, and $g($.$) is approximated by a third-$ order polynomial expansion of $\Pi_{i t-1}$ and $\left(\hat{\lambda}_{t-1}-\beta_{k} k_{i t-1}\right)$, where $\hat{\lambda}_{t-1}$ are the fitted values from the first stage. Since capital enters both in contemporaneous and lagged values, the third stage has to be estimated using non-linear least squares. Ignoring this structure, i.e. not restricting the coefficients on capital to be the same wherever it appears in the estimation of the second stage, would not yield efficient estimates.

\footnotetext{
${ }^{24}$ The partially linear model in (C.3) can be estimated using OLS with a polynomial expansion in $m_{i t}$ and $k_{i t}$ to approximate for the unknown function $\varphi_{t}($.$) , or using kernel estimators. The former approach not only has the$ advantage of being easier and faster to implement, Pakes and Olley (1995) and Levinsohn and Petrin (2003) report that the results of both approaches are very similar.
} 


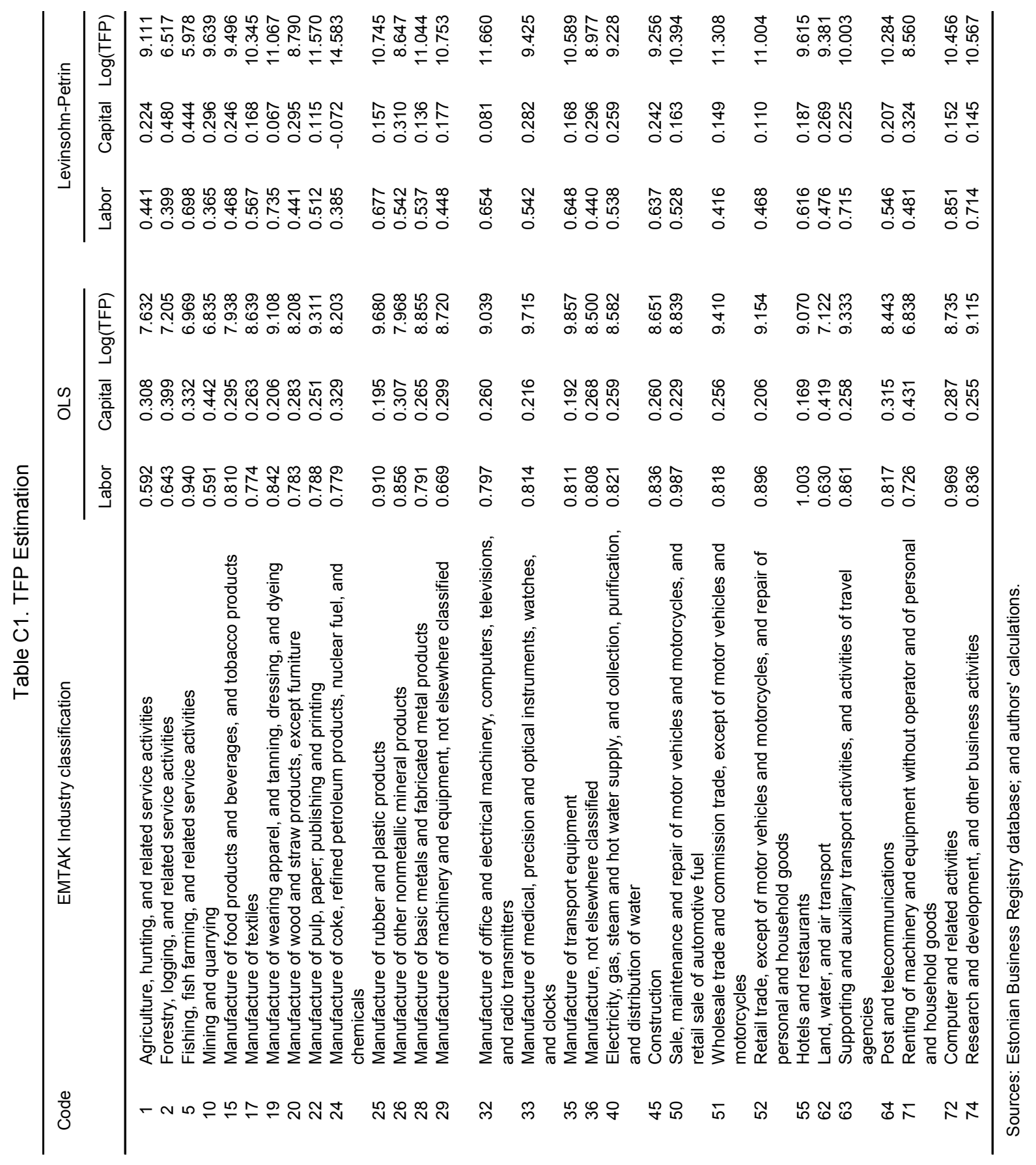




\section{REFERENCES}

Abel, A., and O. Blanchard, 1986, "The Present Value of Profits and Cyclical Movement in Investment," Econometrica, Vol. 54 (No.2), pp. 249-73.

Ackerberg, D., Caves, K., and G. Frazer, 2005, "Structural Identification of Production Functions", unpublished manuscript.

Aghion, P., G. Angeletos, A. Banerjee, and K. Manova, 2005, "Volatility and Growth: Credit Constraints and Productivity-Enhancing Investment," NBER Working Paper No. 11349 (Cambridge, Massachusetts: National Bureau of Economic Research).

Aghion, P., P. Askenazy, N. Berman, G. Cette, and L. Eymard, 2007, "Credit Constraints and the Cyclicality of R\&D Investment: Evidence from France," Weatherhead Center for International Affairs Working Paper No. 2007-4 (Boston: Harvard University).

Almeida, H., and M. Campello, 2007, Financial Constraints, "Asset Tangibility, and Corporate Investment," Review of Financial Studies, Vol. 20 (No.5), pp. 1429-60.

Amiti, M., and J. Konings, 2007, “Trade Liberalization, Intermediate Inputs, and Productivity: Evidence from Indonesia," American Economic Review, Vol. 97 (No.5), pp. 1611-38.

Arellano, M., and S. Bond, 1991, "Some Tests of Specification for Panel Data: Monte Carlo Evidence and an Application to Employment Equations," Review of Economic Studies, Vol. 58 (No.2), pp. 277-97.

Arellano, M., and O. Bover, 1995, "Another Look at the Instrumental-Variable Estimation of Error-Components Models," Journal of Econometrics, Vol. 68 (No.1), pp. 29-51.

Arestis, P., P. Demetriades, and B. Fattouh, 2003, "Financial Policies and the Aggregate Productivity of the Capital Stock: Evidence from Developed and Developing Economies," Eastern Economic Journal, Vol. 29 (Spring), pp. 217-42.

Aterido, R., M. Hallward-Driemeier, and C. Pages, 2007, "Investment Climate and Employment Growth: The Impact of Access to Finance, Corruption and Regulations across Firms”, IZA Discussion Paper No. 3138 (Bonn: Institute for the Study of Labor).

Ayyagari, M., A. Demirgüç-Kunt, and V. Maksimovic, 2007, "Firm Innovation in Emerging Markets," World Bank Policy Research Paper No. 4157 (Washington: World Bank).

Beck, T., R. Levine, and N. Loayza, 2000, "Financial Intermediation and Growth: Causality and Causes," Journal of Monetary Economics, Vol. 46 (August), pp. 31-77.

Bencivenga, V., B. Smith, and R. Starr, 1995, “Transaction Costs, Technological Choice, and Endogenous Growth,” Journal of Economic Theory, Vol. 67, pp. 153-77.

Bhide, A., 1993, “The Hidden Costs of Stock Market Liquidity," Journal of Financial Economics, Vol. 34 (No. 2), pp. 31-51.

Blundell, R., and S. Bond, 1998, "Initial Condition and Moment Restrictions in Dynamic Panel Data Models," Journal of Econometrics, Vol. 87 (No. 1), pp. 115-43. 
Bond, S., J. Elston, J. Mairess, and B. Mulkay, 2003, "Financial Factors and Investment in Belgium, France, Germany, and the United Kingdom: A Comparison using Company Panel Data," Review of Economics and Statistics, Vol. 85 (No. 1), pp. 153-65.

Bond, S., and C. Meghir, 1994, "Dynamic Investment Models and the Firm's Financial Policy," Review of Economic Studies, Vol. 61, (No. 2), pp. 197-222.

Budina, N., H. Garretsen, and E. de Jong, 2000, "Liquidity Constraints and Investment in Transition Economies: The Case of Bulgaria," Economics of Transition, Vol. 8 (No. 2), pp. 453-75.

Canepa, A., and P. Stoneman, 2008, "Financial Constraints to Innovation in the UK: Evidence from CIS2 and CIS3," Oxford Economic Papers, Vol. 60 (4), pp. 711-30.

De Loecker, J., 2007, "Do Exports Generate Higher Productivity? Evidence from Slovenia," Journal of International Economics, Vol. 73 (No. 1), pp. 69-98.

Fazzari, S., G. Hubbard and B. Peterson, 1988, "Financing Constraints and Corporate Investment," Brookings Paper on Economic Activity: 1, pp. 141-95.

Fernandes, A., 2007, “Trade Policy, Trade Volumes and Plant-level Productivity in Colombian Manufacturing Industries," Journal of International Economics, Vol. 71 (No. 2), pp. 52-71.

Forbes, K., 2007, "One Cost of the Chilean Capital Controls: Increased Financial Constraints for Smaller Traded Firms," Journal of International Economics, Vol. 71 (No. 2), pp. 294-323.

Gatti, R., and I. Love, 2008, "Does Access to Credit Improve Productivity? Evidence from Bulgarian Firms?," Economics of Transition Vol. 16 (No. 3), pp. 445-65.

Ghani, E., and V. Suri, 1999, "Productivity Growth, Capital Accumulation, and the Banking Sector: Some Lessons from Malaysia," World Bank Policy Research Working Paper No. 2252 (Washington: World Bank).

Gilchrist, S., and C. Himmelberg, 1999, "Investment, Fundamentals and Finance,” NBER Macroeconomic Annual 1998 (Cambridge, Massachusetts: National Bureau of Economic Research).

Grabowski, H., and D. Mueller, 1972, "Managerial and Stockholder Welfare Models of Firm Expenditures," Review of Economics and Statistics, Vol. 54 (February), pp. 9-24.

Harrison, A., I. Love, and M. McMillan, 2004, "Global Capital Flows and Financing Constraints," Journal of Development Economics, Vol. 75 (No. 1), pp. 269-301.

Harrison, A., and M. McMillan, 2003, "Does Direct Foreign Investment Affect Domestic Firms Credit Constraints?” Journal of International Economics, Vol. 61(No. 1), pp. 73-100.

Hayashi, F., 1982, “Tobin's Marginal q and Average q: A Neoclassical Interpretation,” Econometrica, Vol. 50 (January), pp. 213-24.

Horowitz, J., 2001, “The Bootstrap", in Handbook of Econometrics, Vol. 5, ed. by J. Heckman and E. Leamer (Amsterdam: Elsevier Science), pp. 3159-228.

Hovakimian, G., and S. Titman, 2006, “Corporate Investment with Financial Constraints: 
Sensitivity of Investment to Funds from Voluntary Asset Sales," Journal of Money, Credit, and Banking, Vol. 38 (No. 2), pp. 357-74.

$\mathrm{Hu}, \mathrm{X}$., and F. Schiantarelli, 1998, "Investment and Capital Market Imperfections: A Switching Regression Approach Using U.S. Firm Panel Data," Review of Economics and Statistics, Vol. 80 (No. 3), pp. 466-79.

Hubbard, G., 1998, “Capital-Market Imperfections and Investment," Journal of Economic Literature, Vol. 36 (No. 1), pp. 193-225.

Jensen, M., and W. Meckling, 1976, "Theory of the Firm: Managerial Behavior, Agency Costs, and Ownership Structure,” Journal of Financial Economics, Vol. 3 (No. 4), pp. 305-60.

Kaplan, S., and L. Zingales, 1997, "Do Investment-Cash Flow Sensitivities Provide Useful Measures of Financing Constraints?" Quarterly Journal of Economics, Vol. 112 (No. 1), pp. 169-15.

King, R., and R. Levine, 1993a, "Finance, Entrepreneurship, and Growth: Theory and Evidence," Journal of Monetary Economics, Vol. 32 (No. 3), pp. 513-42. , 1993b, "Finance and Growth: Schumpeter Might Be Right," Quarterly Journal of Economics, Vol. 108 (No. 4), pp. 717-38.

Konings, J., N. Rizov, and H. Vandenbussche, 2003, "Investment and Financial Constraints in Transition Economies: Micro Evidence from Poland, the Czech Republic, Bulgaria, and Romania,” Economic Letters, Vol. 78 (No. 2), pp. 253-58.

Kornai, J., 1979, "Resource-Constrained Versus Demand-Constrained Systems," Econometrica, Vol. 47 (No. 4), pp. 801-19.

— , 1986, “The Soft Budget Constraint,” Kyklos, Vol. 39 (No. 1), pp. 3-30.

Laeven, L., 2003, “Does Financial Liberalization Reduce Financing Constraints?” Financial Management (Spring), pp. 5-34.

Lang, L., E. Ofek, and R. Stulz, 1996, "Leverage, Investment, and Firm Growth,” Journal of Financial Economics, Vol. 40 (No. 1), pp. 3-29.

Lättemäe, R., 2007, “Estonia's Experience with Rapid Credit Growth”, in Rapid Credit Growth in Central and Eastern Europe. Endless Boom or Early Warning? (Eds. Charles Enoch and Inci Ötker-Robe).

Levine, R., 1991, "Stock Markets, Growth, and Tax Policy," Journal of Finance, Vol. 46, No. 4, pp. 1445-65.

— 1997, "Financial Development and Growth: Views and Agenda," Journal of Economic Literature, Vol. 35 (June), pp. 688-726.

- 2005, Finance and Growth: Theory and Evidence, in Handbook of Economic Growth, ed. by P. Aghion and S. Durlauf (Amsterdam: Elsevier).

Levinsohn, J., and A. Petrin, 2003, "Estimating Production Functions Using Inputs to Control Unobservables," Review of Economic Studies, Vol. 70 (No. 2), pp. 317-41.

Lizal, L., and J. Svejnar, 2002, "Investment, Credit Rationing, and the Soft Budget 
Constraint: Evidence from Czech Panel Data," Review of Economics and Statistics, Vol. 84 (No. 2), pp. 353-70.

Love, I, 2003, "Financial Development and Financing Constraints: International Evidence from the Structural Investment Model," Review of Financial Studies, Vol. 16 (No. 3), pp. 76591.

Masso, J., R. Eamets, and K. Philips, 2004, "Firm Demographics and Productivity Dynamics in Estonia," University of Tartu Faculty of Economics and Business Administration Working Paper No. 25 (Tartu, Estonia: University of Tartu, Faculty of Economics and Business Administration).

Modigliani, F., and M. Miller, 1958, "The Cost of Capital, Corporation Finance, and the Theory of Investment," American Economic Review, Vol. 48 (No. 3), pp. 261-97.

Moreno Badia, M., 2007, "Medium-term Growth and Productivity in Estonia: A Micro Perspective," in Estonia - Selected Issues, IMF Country Report No. 07/257 (Washington: International Monetary Fund).

— and V. Slootmaekers, 2008, "The missing link between financial constraints and productivity," LICOS Discussion Paper Series 208/2008.

Myers, S., 1977, "Determinants of Corporate Borrowing," Journal of Financial Economics, Vol. 5 (No. 2), pp. 147-175.

OECD, 2006, The SME Financing Gap (Vol. I): Theory and Evidence (Paris: OECD).

Olley, S., and A. Pakes, 1996, "The Dynamics of Productivity in the Telecommunications Equipment Industry," Econometrica, Vol. 64 (No. 6), pp. 1263-97.

Pakes, A., and S. Olley, 1995, "A Limit Theorem for a Smooth Class of Semiparametric Estimators," Journal of Econometrics, Vol. 65 (No. 1), pp. 1-8.

Power, L., 1998, “The Missing Link: Technology, Investment, and Productivity,” The Review of Economics and Statistics, Vol. 80, No. 2, pp. 300-313.

Rioja, F., and N. Valev, 2004, "Finance and the Sources of Growth at Various Stages of Economic Development," Economic Inquiry, Vol. 42 (No.1), pp. 127-140.

Schiantarelli, F., 1996, "Financial Constraints and Investment: Methodological Issues and International Evidence," Oxford Review of Economic Policy, Vol. 12 (No. 2), pp. 70-89.

Shleifer, A, and R. Vishny, 1986, "Large Shareholders and Corporate Control," Journal of Political Economy, Vol. 96 (No. 3), pp. 461-88.

Stein, J., 2001, "Agency, Information and Corporate Investment," in Handbook of the Economics of Finance, ed. by G. Constantinides, M. Harris, and R. Stulz (Amsterdam: Elsevier).

Solow, R., 1957, "Technical Change and the Aggregate Production," Review of Economics and Statistics, Vol. 29 (August), pp. 312-20.

Tobin, J., 1969, “A General Equilibrium Approach to Monetary Theory,” Journal of Money Credit and Banking, Vol. 1 (February), pp. 15-29.

Van Biesebroeck, J., 2005, "Exporting Raises Productivity in Sub-Saharan African Manufacturing Firms," Journal of International Economics, Vol. 67 (No. 2), pp. 373-91. 